\title{
ESTUDIOS
}

\section{La historicidad de imágenes oníricas quechuas sudperuanas}

\author{
BRUCE MANnheiM** \\ Universidad de Michigan \\ mannheim@umich.edu
}

\begin{abstract}
Resumen
Las imágenes semióticas están enlazadas a sus modos de interpretación y siempre, de una forma específica, a una cultura. Para este estudio usamos la descripción de la interpretación de sueños quechuas sudperuanos presente en el Ritual formulario de Pérez Bocanegra junto a la etnografía contemporánea. Nuestro objetivo es mostrar que el modo de interpretación de los signos oníricos es distinto de los signos narrativos y rituales, aun cuando los mismos signos se usen a través de estos medios. Los signos narrativos se anclan en relaciones sintácticas, los signos rituales en relaciones tanto sintácticas como pragmáticas. Por lo tanto, estos últimos tienen una estabilidad diacrónica mayor que los signos oníricos. Este trabajo es un paso a una teoría general de la estabilidad de formas culturales, a través de anclas y replicadores semióticos.
\end{abstract}

Palabras claves: Cultura, semiótica, Quechua, historicidad, sueños, narrativa, ritual, anclas semioticas

\begin{abstract}
Semiotic images are bound to their culture-specific mode of interpretation. Drawing on Pérez Bocanegra's 1631 discussion of dream interpretation in his Ritual formulario and on contemporary field research in the

* Versión traducida del inglés (Mannheim 1992) por el Dr. Guillermo Salas Carreño y repasada y actualizada por el autor. Agradezco a la Dra. Margarita Huayhua por sus comentarios a la
\end{abstract} versión final. 
same parish in which Pérez Bocanegra worked, I show that the semiotic mode of interpretation of Southern Peruvian Quechua dream signs is distinct from that of narrative signs and ritual signs, even when the same signs are deployed across these media. Narrative signs are anchored syntactically, and ritual signs syntactically and pragmatically they have great historical stability than do dream signs, which are relatively fluid. This represents a step toward a theory of semiotic anchors and replicators.

Keywords: Culture, semiotic, Quechua, historicity, dreams narrative, ritual, semiotic anchor

Recibido: 12/3/2015 Aceptado: 30/5/2015

\title{
Introducción: Humo negro, un águila y una revolución.
}

Antes de la invasión europea y después de ella, en la vida cotidiana y en tiempos de crisis, los pobladores de los Andes guiaban su conducta con sus sueños. En el drama Atau Uallpac Ppuchucacuininpa Uaucan, 'La wanka del ocaso de Atawallpa,' Atawallpa se había despertado dos noches consecutivas atormentando por sus sueños: ${ }^{1}$

\author{
musccuiniipiri ricuni \\ Ynti maillic taitanchicta \\ yana ccusñipi pacasccata \\ llapa hanac pachataca \\ llapa urccucunatauanri \\ puca puca raurascaccta \\ pillcucunac ccascuntahina \\ Y en mi sueño vi. \\ al Sol, nuestro padre,
}

1 La wanka de la caída de Atawallpa es uno de los muchos dramas de la conquista que se representan anualmente en ciudades y pueblos de los Andes Centrales (Wachtel 1967; 1971: tomo I, cap. 2; Husson 2000). El texto que cito fue escrito en Chayanta, Bolivia en 1877 y publicada por el novelista boliviano Jesús Lara (1957) en una versión transliterada del quechua con una traducción al castellano. El fragmento usado aquí corresponde a la primera página del manuscrito reproducido en facsímil (Lara 1957: 16). He conservado la ortografía del manuscrito en lugar de la transliteración de Lara. (Ver Itier [2000] y Husson [2006] para una discusión de la procedencia del manuscrito). La tradición del sueño de Atawallpa refleja una estrategia narrativa común en el quechua sureño en la cual los recuerdos de sueños son usados para introducir eventos especialmente significativos. Esto ha sido observado por Christine Greenway (comunicación personal, 1990) en narrativas de historias de vida de mujeres. 
que nos baña con su luminosidad2

oculto por humo negro

todos los cielos

todas las montañas mas

ardiendo rojo, rojo

como los pechos de una bandada de pájaros

El Inka describe la escena más terrible, en la cual los "enemigos, gente de hierro3, vinieron a nuestra tierra, se meten en nuestras casas, y se llevan a mi real persona". El Inka pide al sumo sacerdote, "aquel que duerme" que duerma para interpretar los sueños del Inka con los propios. El sumo sacerdote vuelve con deprimentes noticias: los sueños del Inka son verdaderos, y también en los suyos "gente roja, barbada, venia del otro lado del mar, en botes de hierro" (Lara 1957: 76). Los sueños del último Inka, Atawallpa, presagiaron la llegada de los españoles.

En la década de 1550, un pequeño grupo de misioneros agustinos viajaba a través del Perú, buscando desenmascarar prácticas religiosas nativas (San Pedro et al. 1865[1559]). Estaban convencidos que estas eran obra del demonio. Sólo así podían explicarse la resistencia con la cual las poblaciones nativas los recibían, quienes incluso habían envenenado a su traductor. El envenenamiento convenció a los misioneros que habían descubierto un culto satánico clandestino y altamente organizado que incluía sus propios sacerdotes. En Huamachuco, Shullka Manqu, el principal 'sacerdote' indígena, confesó que se había hecho 'sacerdote' porque un águila se le apareció en sus sueños dos o tres noches consecutivas. Se sentía perseguido por el águila, perdió el sueño, empezó a enflaquecer, y estaba volviéndose loco cuando el demonio se le presentó y le dijo que era el águila. El demonio le dijo que lo amaba y que lo quería como su sirviente, prometiéndole también hacerle rico. El pobre hombre estaba alborozado (San Pedro et al. 1865[1559]: 16).

\section{米米}

2 "Purificador" en la traducción de Lara

3 La frase 'gente de hierro' es q'illay runakuna en la transliteración de Lara. La palabra q'illay no se usa normalmente para referirse al 'hierro'. Es más bien usada como el verbo 'arañar'; o como un sustantivo que se refiere a una cicatriz. Lara traduce el pasaje como 'hombres vestidos de agresivo hierro'. La traducción de 'fierro' por q'ella [= q'illa] la he podido encontrar solamente en el diccionario de quechua boliviano del propio Lara (1971: 228). 
Durante las postrimerías del Imperio Español, Gabriel Aguilar, un criollo cuzqueño, tuvo sueños en los cuales ascendía a los cielos y le era mostrado su destino: derrocar el orden colonial y anunciar la venida de un nuevo Inka (Flores Galindo 1987: cap. 4)4. Los sueños-profecías de Aguilar convencieron a Manuel Ubalde, quien soñó que Aguilar convertido en un águila coronado empezaba a volar. El águila llevaba a Ubalde en su espalda, junto con una mujer y otro hombre. Lo dejaba en un campo, donde Ubalde llamaba la atención de muchos nativos andinos. Ubalde observó que el águila volaba hacia el mar, donde se encontró con otra águila cuya corona se caía. Las dos águilas pelearon (Flores Galindo 1987: 194-5).

Ubalde interpretó el sueño como una señal del llamado divino de Aguilar para guiar la rebelión peruana contra el imperio español y restaurar el trono Inka. Las imágenes del sueño de Ubalde no dejan mucho a la imaginación: El águila coronado es un emblema convencional de un imperio. Aguilar, como su nombre lo indica, es un águila. Aguilar se enfrenta en batalla a otra águila de corona precaria, que representa el decadente imperio español. (El águila era precisamente el emblema del imperio Habsburgo que por aquella época ya había dejado el poder en España.) Finalmente, Aguilar y Ubalde fueron descubiertos planificando una insurrección, junto con otros criollos y un descendiente de los Inkas a quien habían planeado coronar. Durante su juicio, Aguilar usó sus sueños para explicar sus acciones. Los últimos sueños de Aguilar presagiaron su ejecución.

La generación de Aguilar vivió un periodo de fuerte turbulencia social, incluida la 'Gran Rebelión' dirigida por Thupa Amaru y Micaela Bastidas (1781), que buscó expulsar a los españoles del Perú. Cuando niño, fue testigo de la destrucción de haciendas y el asesinato de 'españoles' (en la práctica así era nombrado cualquiera visto como explotador por los débilmente confederados rebeldes).

También fue testigo de la desestructuración social de comunidades indígenas como consecuencia de la rebelión y de la brutal represión del ejército imperial español. Aguilar no era un 'soñador' ingenuo. Debió estar consciente de las consecuencias que enfrentaría al actuar de acuerdo a sus sueños, especialmente los riesgos físicos que esto suponía para gente de un estrato criollo como él. No solamente corría riesgos al conspirar contra la corona española, sino que en el caso de que su rebelión fuese exitosa, también podría haber sido identificado como español y asesinado por los rebeldes.

4 Alberto Flores Galindo discute los sueños-profecías de Aguilar en su excelente libro Buscando un Inca (1987, cap. 4). 
Para cada uno de estos hombres, Atawallpa, Shullka Manqu y Gabriel Aguilar, los sueños eran augurios, guías de sus destinos inexorables. Atawallpa vio el colapso de su imperio; Shullka Manqu su futuro llamado como sacerdotechamán; y Aguilar su futuro rol en instigar una rebelión que traería de vuelta al Inka. Concedo que la información sobre estos casos provienen de documentos creados en circunstancias inusuales: la tradición de los sueños de Atawallpa proviene de un drama quechua del s. XIX; el testimonio de Shullka Manqu fue obtenido indudablemente bajo coacción física; y los sueños de Gabriel Aguilar se registraron como parte de la evidencia durante un juicio por sedición. Difícilmente son estas las mejores condiciones etnográficas. Sin embargo, estos apuntan a una peculiar fe andina en el valor de las imágenes oníricas, y una resignación andina ante el futuro que los sueños predicen.

Hay otro sentido en el cual estos hombres actuaron de acuerdo a ideas peculiarmente andinas sobre qué son los sueños y cómo deben ser entendidos. Ellos 'vivieron sus sueños' aunque en un sentido distinto al que se da a esta frase en español o en inglés. Sus sueños fueron involuntarios y extra personales, eran visiones inevitables de cosas por suceder. En contraste, cuando se dice que alguien 'vive sus sueños' en español o en inglés quiere decir que ellos siguen una visión interior que guía su conducta cotidiana o que sus ambiciones son dirigidas por un conjunto de objetivos personales. El entendimiento andino de los sueños está construido usando diferentes esquemas causales o etiológicos, es decir los sueños andinos están fuera del cuerpo del individuo, en el mundo; mientras los nuestros expresan los deseos y preceptos más íntimos de los individuos soñantes (v. Andrade 2010: 18-20). La interpretación andina de los sueños presupone que las imágenes de los sueños ingresan en quien sueña desde fuera. La interpretación europea-americana presupone que los sueños son creados por los individuos5. En el mundo europeo-americano post freudiano, los sueños son una forma de acceder a las patologías individuales, patologías que articulan peligros psíquicos, familiares y sociales. En cambio los sueños andinos juegan un rol neutral en la economía moral del individuo.

En una cultura como la de los europeos-americanos, en la cual el individualismo y la privacidad son valores primordiales, los sueños son la experiencia más profundamente individual y privada que hay. De manera similar a como entendemos la 'creatividad', el soñar es algo irreductiblemente individual aunque se encuentre más allá del control racional del individuo. ¿Qué otra cosa puede ser más similar a 'un virus que proviene del espacio'-en las palabras del nove-

5 Aquí uso deliberadamente la palabra 'crear'. Las nociones occidentales modernas de 'creatividad' asumen similarmente que ésta sólo puede ser atribuida a un individuo autónomo (ver Feyerabend 1987).

LETRAS 86 (123), 2015 
lista William Burroughs-que la danza de imágenes que experimentamos cuando dormimos? ¿Que voz podría parecerse más a la voz de 'el amo del mundo de abajo'-en las palabras del antropólogo y poeta Paul Friedrich (1986[1985]: 79)-que aquello a lo cual estamos sujetos cuando soñamos, aún si es sólo para suprimirlo, contarlo a un psicoanalista o traducirlo en un poema? Este es un tema familiar romántico: los sueños son experiencias individuales que revelan ansiedades y deseos ocultos, y son el escape a la racionalidad sofocante de la vida diaria. Sin embargo, aceptar estos presupuestos-no importa cuán profundamente estemos convencidos de ellos-nos impediría preguntarnos si el soñar e interpretar sueños en la cultura quechua de la sierra surperuana son efectivamente iguales o difieren a los correspondientes entre los europeos y los euro-americanos 6 ¿Cuál es la sociología de la interpretación de sueños en la cultura quechua surperuano? ¿Cuál es el lugar del soñar y del interpretar los sueños en sus vidas cotidianas? ¿Cómo son estructurados los sueños entre los quechuas surperuanos? ¿Cuál es la relación entre soñar e interpretar sueños? ¿Cómo están relacionados el soñar y otros sistemas semióticos? ¿Los quechuahablantes se preocupan en entender el soñar como una categoría abstracta como los europeos y los euro-americanos? ¿Tienen teorías sobre el soñar como los psicoanalistas, los antiguos mesopotámicos y los griegos, o los mayas contemporáneos?

Trataré de responder a estas preguntas discutiendo qué es lo que los quechuahablantes del sur del Perú hacen después de soñar. La naturaleza y el contenido de los sueños en el quechua surperuano están determinados por el proceso de interpretación (Mannheim 1987)7. Los sueños en el quechua sur-

6 En este artículo, uso ‘quechua surperuano’ para referirme al idioma quechua del sur del Perú hablado hoy por alrededor de varios millones de personas en seis departamentos: Apurímac, Ayacucho, Arequipa, Cuzco, Huancavelica y Puno (ver Mannheim 1991:4-16). Esta lengua era hablado por los inkas antes de la invasión europea. La expresión quechua surperuano para su idioma es runa simi 'lenguaje humano en términos genéricos mas no como nombre propio. No sólo el nombre 'quechua' les fue impuesto en un contexto colonial (ver Mannehim 1991a: 6-8), sino también por la idea de que tanto las lenguas como las poblaciones deben tener nombres. Runa y runa simi son términos genéricos usados en situaciones especificas para expresar una diferencia de identidad, junto con expresiones como campesino en oposición a misti, q'ara y español, todos términos para referirse a quienes no son quechuas (Isbell 1978, Allen 1988; en contraste v. Huayhua 2010: 66-72, que expone un deseo por parte de quechuahablantes de no ser clasificado por ningún término). Para una clasificación de lenguajes quechuas ver Cerrón Palomino (1987); Parker (2013); y Torero (1974).

7 En mi anterior artículo sobre soñar, omití mencionar dos discusiones sobre la interpretación de sueños en comunidades Aymaras. Hickman (1961: 78-80) discute las interpretaciones de sueños y augurios en Chuchito (Puno, Perú) observando que el significado de las imágenes de los sueños varia ampliamente de persona a persona. Cole (1969: 60-110), quien trabajó en Untavi (Oruro, Bolivia), sugiere que la interpretación de sueños toma en cuenta ideas de quien 
peruano predicen los acontecimientos del día. Temprano en la mañana, los quechuahablantes narran sus sueños a sus familiares cercanos o a sus amigos, y discuten su interpretación. Interpretan sus sueños seleccionando una imagen u otro signo del sueño y lo descifran, usando un léxico fluido de signos oníricos. El proceso de interpretación determina el significado de los signos oníricos e indudablemente prefigura su aparición en los sueños en la primera instancia.

Mi planteamiento va más allá: la estructura formal de la interpretación de sueños determina la velocidad con la que las imágenes de sueños cambian en el tiempo, comparados a otros sistemas semióticos quechuas, como aquellos encontrados en el ritual y el mito. No sólo los signos de los sueños cambian más rápidamente que aquellos de otros sistemas semióticos, sino que también muestran mayor variabilidad de individuo a individuo (cfr. Hickman 1964: 7880; Cole 1969: 63). Ha sido casi obligatorio enfatizar la transitoriedad e inestabilidad de la cultura (ver, por ejemplo, Clifford 1988: 95, 233-34), pero no todos los dominios semióticos son igualmente inestables. ¿Por qué en quechua las imágenes de sueños son más fluidas que los signos en los mitos y el ritual? Esta pregunta apunta a un problema más general: ¿cómo los patrones culturales se cristalizan y persisten en un escenario de caos e inestabilidad? (Mannheim \& Tedlock 1995; Mannheim 2012).

El propósito de este texto es examinar por qué los signos oníricos son menos estables que los de otros sistemas semióticos del quechua surperuano. En las siguientes secciones ( 2 y 4 ), sostendré que los signos de los sueños son menos estables que los del ritual o del mito por la manera en cómo son interpretados. En la interpretación de sueños quechua, signos individuales son extraídos de sus contextos sintáctico y pragmático, e interpretados aisladamente (sección 3). En contraste, los signos de la narrativa del quechua sureño son interpretados en grupos sintácticos que anclan el valor de un signo al de los otros. De forma similar, los signos del ritual son interpretados en conjuntos sintácticos y, además están anclados mediante relaciones convencionales con los participantes de un ritual (sección 4). Estas relaciones convencionales entre

\footnotetext{
tuvo el sueño (pero no las del intérprete). Además de estos trabajos en la interpretación de sueños en los Andes y de aquellos citados en mi anterior artículo (Mannheim 1987), quisiera mencionar los textos de Moya (1987[1982], 1988), quien discute imágenes de sueños en la sierra ecuatoriana; Preloran (1987), quien estudia creencias sobre la interpretación de sueños en Otavalo (Ecuador); el estudio de Ackerman (1985) sobre San Pedro de Cachora (Apurímac, Perú) que incluye un apéndice sobre augurios de sueños; la breve discusión de Bastien (1987: 44) sobre el uso de los sueños por curanderos Kallawaya; el estudio de Tandioy (1987) sobre augurios de sueños de hablantes de Inga en el valle de Sibundoy al sur de Colombia; y el agudo análisis de McDowell (1989) sobre sueños como una ventana en el mundo cultural de la misma población. Cabe mencionar también el trabajo impresionante de Andrade Ciudad (2005).
} 
signos, y entre éstos y quienes los usan, dan a la narrativa y al ritual un grado de estabilidad histórica ausente en los signos de los sueños. (La estabilidad histórica en la narrativa y el ritual es notable, considerando las disrupciones sociales que los quechuahablantes surperuanos han sufrido durante casi cinco siglos después de la invasión europea.)

La estructura de la interpretación de sueños es necesaria - pero no suficiente - para explicar la inestabilidad de los signos de los sueños. Es también importante que el soñar y su interpretación no sean objeto de un sistema de creencias socialmente organizado (sección 5). No estoy sugiriendo que los quechuahablantes nunca especulan acerca de la naturaleza del soñar y de la interpretación de los sueños. Lo que sostengo es que esta especulación es individual y no social. En consecuencia, no existe una tradición de teorizar acerca de la interpretación de los sueños o acerca de los significados de las imágenes en los sueños. Los hablantes del quechua surperuano no tienen tradiciones desarrolladas de exégesis nativa sobre el soñar, o sobre otros aspectos de su cultura8.

La ausencia de una tradición de exégesis es crítico para mi argumento. Aún si un sistema de interpretación como el del quechua sureño, en el cual las imágenes de los sueños se extraen de sus contextos sintácticos y pragmáticos, los significados de las imágenes podrían ser estabilizados a través de una tradición socialmente organizada de hablar acerca de ellos. La exégesis nativa-sea hecha por especialistas o por gente común-hace más que brindar acceso a los significados de las formas simbólicas. Esta práctica autoriza ciertas explicaciones y ciertos estilos de explicación, las muestra como socialmente apropiadas, legitima a algunos individuos como expertos, y estabiliza la interpretación de las formas simbólicas. La ausencia de una tradición de exégesis quita los medios culturales por los cuales el sistema de interpretación de sueños podría ser estabilizado. La estructura de la interpretación de los sueños y la ausencia de una tradición de teorizar sobre ésta explican conjuntamente la inestabilidad de las imágenes de los sueños y su variabilidad dentro de las comunidades.

En este artículo, asumo que el soñar y su interpretación forman juntos un sistema semiótico o cultural, esto es, un sistema convencional de signos que al mismo tiempo se intersecta con, y es autónomo de, otros sistemas culturales, tales como la narrativa y el ritual. Desde el momento en que quien sueña o el etnógrafo son capaces de observar sueños, éstos son más que solamente una 'experiencia' o una 'causa ausente' electroquímica. Los sueños son enteramen-

8 En este sentido, los hablantes de quechua surperuano difieren de otros originarios sudamericanos, como de sus parientes en la amazonia ecuatoriana, quienes tienen una compleja tradición de exégesis. Retornaré a este punto en la sección final del artículo. 
te culturales, 'públicos' en un sentido Geertziano (1973: 10-13), en el cual las imágenes y las interpretaciones están constituidas dentro de y por la acción social (ver Dentan 1988:53). Sin embargo, para evitar malentendidos respecto a la palabra 'público', enfatizaré que para los quechuas rurales surperuanos, la interpretación de sueños es un asunto intensamente privado, algo que debe hacerse solamente con familiares y amigos cercanos. También, para evitar otro tipo de malentendido, enfatizaré que cuando digo que el soñar es un 'sistema cultural' no quiero decir que los sueños estén fuera de la política de la vida cotidiana. Los sueños están profundamente inmersos en la dominación sociocultural a la que está sujeta la gente rural en el Perú contemporáneo. Esto no podría ser más claramente ilustrado que en la imagen del policía en los sueños, que-se dicen-representa a Dios.

La afirmación que el soñar es un sistema cultural o semiótico tiene tres componentes: (1) soñar se intersecta con otros sistemas culturales; (2) es autónomo de otros sistemas culturales, y (3) es convencional. El soñar se intersecta con otros sistemas culturales en tanto el conjunto de signos de los sueños refleja la práctica y preocupaciones cotidianas, e incluye signos-imágenes derivados de otros sistemas culturales tales como el mito y el ritual. Por ejemplo, en el léxico de sueños registrado por Pérez Bocanegra (1631), una serpiente de dos cabezas representa 'desastre', de forma similar como ocurría en el imaginario mítico y la iconografía visual.9 Pero sostener lo obvio, que los signos de los sueños son también usados en otros sistemas culturales, sería una solución trivial al problema de cómo se relaciona la interpretación de los sueños con otros sistemas culturales. A pesar que muchas imágenes de los sueños también aparecen en otros sistemas culturales, la interpretación de los sueños tiene propiedades específicas que la distinguen de otras practicas simbólicas. La interpretación de los sueños es estructuralmente autónoma: el conjunto de signos, sus conexiones mutuas y sus interpretaciones son propios de los sueños. Dicho de otro modo, la interpretación de los sueños está sujeta a sus propias restricciones y principios de estructuración, como trataré de mostrar en la siguiente sección.

Finalmente, soñar es convencional en tanto que soñar y la interpretación de sueños son actividades socialmente organizadas, realizadas en la interacción cotidiana y sujeta a expectativas recíprocas de los participantes.10 No

9 Ver López-Baralt (1987) para una discusión sobre la iconografía de la serpiente de dos cabezas en los Andes.

10 Estos puntos son desarrollados en la ahora extensa literatura etnográfica sobre el soñar. Ver especialmente Basso (1987), Ewing (1990), Guss (1980), Herat (1987), Ilollan (1989), Kracke (1987), Parman (1991), Perrin (1992), Sanchez Parga (1991), Shaw (1992) y Tedlock (1987). 
hay acceso ninguno al sueño como experiencia privada-aun el soñador mismo 'recuerda' el sueño como una reconstrucción retrospectiva, organizada por las convenciones narrativas de su lenguaje y cultura (Zambrano 1957; Dentan 1988:55). Los sueños son hechos sociales en un sentido Durkheimiano: están 'afuera', son creados entre-y no por -personas (Durkheim 1898: cap. 1; t. Mannheim \& Tedlock 1995: 9-12), son experimentados como 'un virus del espacio sideral' o quizás como la voz de un amo ausente. Al ser convencionales son históricos; cambiantes, y sin embargo estables en el tiempo (Saussure 1971[1915]:104). De esta forma, se torna posible plantear la pregunta de la relativa estabilidad o cambio de los signos de sueños. Mis datos son narraciones de sueños y sus interpretaciones. Con Robert Dentan (1988), reconozco que los estudiosos del soñar-sean antropólogos o psiquiatras- trabajan con narraciones de sueños en lugar de trabajar con sueños propiamente dichos. Sin embargo cuando uso la palabra 'soñar' reconozco también que hay un dominio en común a través de las fronteras cultuales. Tanto las narraciones de sueños en quechua como las narraciones en inglés tienen a los sueños como sus objetos, a pesar de diferencias radicales entre los sistemas interpretativos. Dentan recomienda que distingamos rigurosamente entre narrativas de sueños y los sueños mismos. Sin embargo, si se considera que los 'sueños' están completamente subsumidos en las 'narraciones de sueños' excepto en un sentido psico-biológico, distinguir sueños de narraciones de sueños reestablece una idea metafísica occidental por la cual los sueños no son sociales sino experiencias individuales y privadas. El filósofo Zambrano (1957) ha argumentado que el problema de las narrativas de sueños no es cualitativamente diferente de el problema del referente de cualquier tipo de narrativa-ambas están presupuestos por la narrativa, y son igualmente problemáticos fuera de ella. Sugiero que el punto relevante aquí es el grado en el cual el referente de una narrativa es construida intersubjetivamente, por más de un individuo. Aun si las narrativas de sueños no son cualitativamente distintas de otras narrativas, ellas están en distintos extremos de un continuo: los referentes de las narrativas de sueños son más subjetivos, los referentes de otros tipos de narrativas son más intersubjetivos.

A pesar que algunos pueblos, como los Atabascos Sureños de los EEUU y los Quichuas amazónicos del ecuador atribuyen la misma categoría de realidad a los eventos en los sueños y a aquellos que viven cuando despiertos, para los quechuas surperuanos los sueños son epistemológicamente distintos a otras experiencias. En las descripciones de los lugares, las narrativas de sueños requieren el uso de un sufijo verbal especial que marca eventos que el hablante no puede asegurar personalmente (Mannheim 1987: 140; v. Andrade 2005: cap. 3 , para una discusión de una distinción cognada en el español andino). Los 
eventos que han sido soñados afectan al mundo solamente como augurios; si ellos son contiguos con algún fenómeno del mundo no onírico, se trata de augurios naturales como eclipses, luciérnagas o picaflores.

\section{La interpretación de los sueños en los Andes surperuanos}

Temprano en la mañana, los quechuahablantes surperuanos narran y discuten sus sueños a sus parientes o a sus amigos más cercanos. Los sueños quechuas predicen los eventos del día en una de dos maneras. Ocasionalmente ellos predicen un escenario completo. En esas circunstancias, no es necesaria una interpretación adicional. Pero más comúnmente, el que sueña narra su sueño a un familiar o amigo, y juntos escogen un elemento (o a veces varios) que interpretan usando un léxico fijo de signos de sueños, casi como un libro oral de sueños (compárese Andrade 2005: cap. 2; La Riva González 2010).

Las predicciones de los sueños son sólo válidas durante el día en que han sido soñadas. Bajo circunstancias normales, uno se levanta en la mañana primero con el pie derecho. Pero cuando un mal presagio aparece en un sueño, uno se levanta primero con el pie izquierdo. Antes de conversar con alguien sobre el mal augurio uno tiene que buscar una oveja o llama joven, contarle todo el sueño y luego escupir en su boca tres veces diciendo. 'qulluy, qulluy, qulluy' ('que no ocurra, que no ocurra, que no se ocurra').

En las siguientes narrativas de sueños ofrezco dos interpretaciones. Una--la mía--trata la narrativa del sueño intertextualmente mostrando las resonancias culturales de las narrativas de los sueños, las formas en las cuales estos reflejan otras prácticas y creencias quechuas. Confieso compartir una enfermedad ocupacional con muchos de mis colegas antropólogos: un deseo de interpretar prácticas sociales más elaborada y profusa que cualquier quechuahablante. Desde mi perspectiva como etnógrafo, las narrativas de sueños revelan preocupaciones sociales y culturales peculiarmente andinas. Me parece que ellos también revelan ansiedades acerca de la naturaleza del trabajo etnográfico en el cual registré estas narrativas. Desde la perspectiva de las prácticas andinas de interpretación estas resonancias son irrelevantes. Los significados de los sueños convergen en imágenes aisladas que son augurios de los eventos que se van a vivir ese día. Esto significa que las interpretaciones del etnógrafo son más elaboradas que las nativas. 11

11 Harriet Whitehead (comunicación personal, 1986) sugiere que existen dos sistemas semióticos. Uno estructura las narraciones de sueños y otro gobierna su interpretación. La semiótica de la narrativa funciona interterxtualmente, por medio de resonancias culturales de las imágenes en las narraciones de sueños. En este nivel, no hay una reducción analítica de la narración del 
Unquspas kasqani hinaspa huq wiraqucha niwan 'yawarniykita urquchikamuy.' Chaymanta 'kinsa unchayninmanta kutimunki,' nispa niwan. Chayqa rini yawarniy urquchikuq. Chay hatun wasipi haykuqtiy ishkay mistikuna chuqlluta mihushasqanku. Huqnin niwan 'tiyaykuy' nispa. Chaymantan kunapi huq mankapi pisqa chuqlluhina karan ichaqa ishkayninku sumaqta q'illu chuqlluta mihuranku. Chay musqukusqay nuqapaq qulqi tarinaypaq karan.

Estaba enferma entonces un wiraqucha (alguien que no es quechua, honorífico) me dijo 've a que te saquen sangre.' Después me dijo 'vuelve en tres días.' Así que, voy a que me saquen sangre. Cuando entro en esa casa grande dos mistis (alguien que no es quechua) comían choclos. Uno de ellos me dijo 'siéntate.' Entonces, en una olla encima de una cuna había como cinco choclos. Pero, sólo los dos comieron el delicioso choclo amarillo [sin invitarme a míl. 12 Ese mi sueño [para mi] era para encontrar dinero.

La interpretación comienza recordando el sueño en forma de una narración. Desde mi perspectiva de etnógrafo de los Andes, la narrativa refleja profundas ansiedades culturales acerca de aquellos que no son quechuas. Una mujer está enferma, y alguien que no es quechua (quizás un médico) recomienda que se haga extraer sangre y que vuelva en tres días. La idea de que quienes no son quechuas están interesados en extraer los fluidos vitales de los andinos nativos es muy persistente. Cuarenta años después de la invasión europea, en 1571, se registraron rumores que los europeos habían venido al Perú para consumir los fluidos vitales de los nativos andinos - principalmente la grasa que es considerado un fluido vital en la cultura quechua, pero también sangre. (Molina 1574: 79). Estas sospechas sobre quienes no son quechua persiste actualmente: En la sierra central y sur es muy extendida la idea que quienes no son quechua-especialmente sacerdotes-están interesados en extraer la grasa de los quechuas para fabricar velas para las iglesias, cosméticos, o lubricantes para maquinaria norteamericana. Este tema ha levantado el interés de mas de un etnógrafo, y por lo punto hay una literatura inmensa sobre ello, pero que lo trata mayormente de forma alegórica (para una interpretación contraria, con una bibliografía amplia, v. Mannheim \& van Vleet 2000: 48-51). Mas de una vez, la grabadora de

sueño. En contraste la semiótica de la interpretación requiere una reducción de la narración del sueño a una imagen focal que luego es interpretada como un augurio. Estas observaciones de Whitehead son consistentes con el análisis que presento aquí, dado que ambos grupos de prácticas semióticas conforman una jerarquía en la cual los valores de las imágenes son determinados por la semiótica de la interpretación en lugar que por aquella de la narrativa.

12 La frase entre corchetes no aparece en quechua. En la cultura quechua, si invitas a alguien a sentarse contigo mientras estás comiendo supone que tú estás ofreciendo también compartir tu comida. Pero en este caso las dos personas (ishkayninku) que no son quechua no comparten su comida a quien invitan a sentarse. 
un desafortunado etnógrafo fue confundida con una yawardora, una máquina para extraer sangre. Esta sospecha no distingue el estatus de quien no es quechua: los wiraquchas son tan sospechosos como cualquier otro misti.

Cuando la soñadora llega al sitio donde se le tiene que extraer sangre, encuentra a dos no-quechuas (en este caso referidos con el término misti) que están comiendo choclo. En lugar de sacarle sangre ellos le invitan a sentarse. Normalmente, una invitación a sentarse mientras otros están comiendo es también una invitación a compartir la comida. Pero los mistis no comparten su maíz con ella. De acuerdo al léxico de las imágenes de sueños, el maíz representa dinero. De esta forma, el sueño puede ser interpretado por un etnógrafo como representando la percepción quechua de los mistis: Los mistis rehúsan de forma grosera a compartir su riqueza.

La narrativa del sueño también puede ser interpretada como un comentario sobre las circunstancias en que fue enunciada. Hablando en quechua a un etnógrafo que no es quechua, describe dos encuentros con no-quechuas: el primero en el cual le dicen que tiene que hacerse extraer sangre, y el segundo en el cual las normas quechuas de sociabilidad son violadas. Como una alegoría de la investigación etnográfica, la imagen de la sangre siendo extraída es mordaz.

Pero aquí la lección sobre la política del trabajo de campo es más sutil que lo que sugiere esta interpretación alegórica. Entre el nativo y el etnógrafo hay una distribución desigual de énfasis y autoridad. El etnógrafo interpreta el sueño simbólicamente, tratando la narrativa del sueño como un vehículo de una segunda narrativa oculta, sea esta sobre conflictos de clase y étnicos, o un crítica velada del etnógrafo. (iQue tal narcisismo!). Pero quien soñó interpretó el sueño como un índice, como un augurio; a ella no le interesaron la política de la vida cotidiana ni la política del trabajo de campo etnográfico. Casi toda la narrativa fue descartada excepto un detalle: el maíz amarillo fresco. La imagen del maíz fresco fue seleccionada de la narrativa e interpretada, usando el léxico de las imágenes de sueños: Maíz representa dinero. Más tarde en el día, la que sueña todo lo que dice sobre el sueño es: 'Anoche soñé con maíz amarillo.' Todo el resto del sueño es descartado por la soñadora, a pesar de que podría haber sido revelador de sus ansiedades culturales, políticas y personales.

Mana rikusqay llaqtapi, mantaywan kashasqani. Chay sitio karan lliw q'umir, hatuchachaq mallkikunayuq. Hinaspa huq sullk'achay, mawk'a washkhata k'aspipi muyusqata hap'ishasqa. Hinaspa mantay nin sullk'achayta, 'Maymantan aparamunki chay washkhata? Pasay kasqan sitioman kutichiy,' nispa. Chaymanta sullk'achay nin, 'manan mantay suwakamunichu. Tarirakamuni,' nispa. 'Kusa allin waka watanapaq,' nispa mantay. Chaypi rikch'apuni. 
Estaba con mi mamá en un pueblo en el que nunca había estado antes. Ese sitio era todo verde, lleno de árboles grandes. Entonces, uno de mis hermanas menores tenía una soga usada envuelta en un palo. Entonces, mi mamá dijo a mi hermana menor, 'ide dónde has traído esa soga? Anda, devuélvela'. Entonces mi hermana menor dijo, 'No mamá, no la he robado, la he encontrado'. 'Será muy buena para amarrar las vacas,' dijo mi mamá. Entonces me desperté.

Aquí el narrador describe un lugar desconocido, verde con árboles altos. La madre del narrador y una hermana menor están solas.13 Ellas encuentran una soga que la madre asume fue robada por la hermana menor. En esta narrativa de sueño es la soga la que es seleccionada. La soga predice que un viajero arribará pronto; una soga representa viajar a pie. Cuando presioné por más detalles de la interpretación, me dijeron que quizás la verdura de la escena original podría representar tristeza.

A veces se selecciona más de un signo de una narrativa de sueño. En los inicios de nuestro trabajo de campo, Diane Hopkins y yo estábamos despiertos antes del amanecer.14 Nuestro huésped tuvo un sueño en el cual Hopkins aparecía llamándolo 'papáy, papáy', Ella tenía un saco de papas que había llevado para intercambiarlo con él por un saco de maíz seco. Maíz y papas fueron seleccionados de la narrativa del sueño. El maíz fue interpretado como dinero, las papas como animales, ambas interpretaciones convencionales. Pero esta vez nuestro anfitrión reintegró estos signos en una segunda narrativa, preguntándose qué relevancia tenían para sus circunstancias personales. Había dejado sus animales pastando en un cerro cercano. Interpretó el saco de papas como 'hay carne en el cerro' y que había ladrones quienes estaban planeando sacrificar sus animales llevarse la carne a la capital provincial, donde podrían cambiarla por dinero. Esa madrugada él y yo fuimos al cerro a recuperar los animales. Afortunadamente, llegamos antes que los ladrones.

En este sueño, las imágenes focales tienen resonancias mayores en la interpretación. Las lecturas convencionales del maíz como dinero y de las papas como carne están reforzadas por la presencia de alguien que no es quechua intercambiando maíz por papas. Para los quechuas surperuanos el maíz es la sustancia de la vida, tanto como ellos consideran que el dinero lo es para nosotros. El intercambio de maíz por papas es la quintaesencia de las transacciones de mercancías en los Andes. El maíz es emblemático de zonas templadas; las

13 A pesar de que la terminología de parentesco del quechua surperuano distingue el sexo de los hermanos y hermanas y los hermanos del mismo sexo de aquellos del sexo opuesto, en la práctica los hablantes normalmente se refieren a sus hermanos o hermanas como 'mi mayor' o 'mi menor' sin tomar en cuenta el género del ego o del alter.

14 Este incidente y su interpretación son analizados en Mannheim (1987: 133, 146). 
papas lo son de las zonas altas donde son producidas y donde se pastea el ganado. Hay también una similitud sensible, dentro de la cultura quechua, entre papas y carne.

En cada interpretación, la experiencia del sueño es codificada en una forma narrativa: la narrativa ha sido reducida en una o algunas imágenes claves tomadas de un léxico convencional de imágenes de sueños. Estas imágenes claves son recontextualizadas tomando en cuenta su relevancia respecto a las circunstancias personales de quien soñó y ocasionalmente también considerando otras imágenes clave. Esto está diagramado en la figura 1, a partir de Mannheim (1987: 147).

\section{Experiencia del sueño}

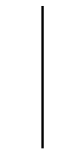

(1) Codificación como narrativa

(2) Reducción
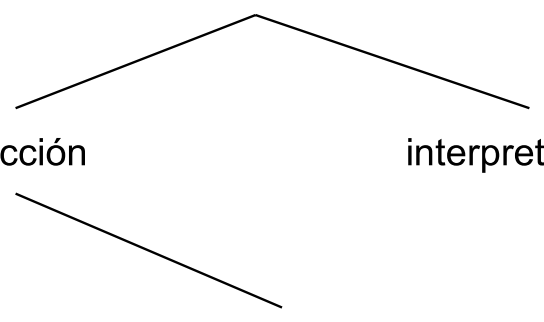

(3) Recontextualización

Figura 1

De vez en cuando, la narración entera—en todos sus detalles—es tratada como un augurio literal de los eventos narrados. El modo normal de interpretación, sin embargo, es tomar imágenes individuales fuera de su contexto narrativo y referirlas al léxico. El punto crucial del proceso interpretativo es el paso reductor, en el cual se busca en la narrativa imágenes que puedan corresponder a un par de imágenes del léxico.15 Estas imágenes incluyen objetos, objetos

15 Es importante notar que la interpretación de sueños en el quechua surperuano utiliza imágenes individuales, asi como también éstas son el foco de la interpretación sin reintegrarlas en un discurso interpretativo convencional más amplio. El ensayo de Kim Seong-Nae (1989) sobre el imaginario histórico de la violencia en la isla Cheju (Corea del Sur) provee un contraste interesante. Kim discute el caso de un chamán coreano que soñó una joven pareja vestida en ropa blanca de luto con sus bocas y pechos sangrantes. Al día siguiente realizó un exorcismo para un joven cuyos padres fueron asesinados en una revuelta local durante la guerra de Corea. El chamán incorporó las imágenes del sueño en una historia vernácula convencional de la revuelta (una revuelta silenciada en las narraciones surcoreanas oficiales de ese periodo) y actuó como un médium a través del cual los padres muertos rememoraban su sufrimiento 
en ciertos estados, atributos, eventos y aun personas concretas. Todas excepto las personas concretas son convencionales. Las personas concretas adquieren significados consistentes para el que sueña después de aparecer repetidamente en sueños y ser correlacionados con los eventos de los siguientes días. Si sueñas con tu cuñado y te enfermas ese o el día siguiente y esto sucede varias veces, tu cuñado va a ser atribuido el significado de "enfermedad.

\section{La estabilidad histórica de las imágenes de sueños}

Para probar la hipótesis de la fluidez histórica de las imágenes de los sueños comparo las prácticas interpretativas modernas con información de inicios del s. XVII. Para la época colonial en el Perú existen no pocas descripciones excelentes realizadas por quienes habían desarrollado un profundo y amplio conocimiento de las prácticas culturales rurales andinas.16 Felipe Guaman Poma de Ayala (1936[1615]:282) incluyó varias imágenes de sueños en una discusión sobre augurios y métodos de pronóstico rurales en su Nueva corónica y buen gobierno. Juan Pérez de Bocanegra, contemporáneo de Guamán Poma y párroco rural en el Cuzco, también discutió interpretaciones de sueños en su manual para sacerdotes escrito en quechua Ritual formulario e institución de curas (1631). Pérez Bocanegra era un dotado escritor en quechua surperuano quien tenia una larga relación con la parroquia rural de Andahuaylillas (Quispicanchi, Cuzco), incluyendo familiares suyos quienes vivían en ella. Su manual para sacerdotes rurales es una de las fuentes más importantes para entender la naturaleza de la amalgama colonial de prácticas rituales andinas con el catolicismo (v. Mannheim 2015b). Tanto las descripciones de interpretación de sueños de Guamán Poma como de Pérez Bocanegra son consistentes con las prácticas modernas en tanto ambas describen un sistema construido alrededor de la interpretación de imágenes individuales tomadas de un léxico. Usan el mismo lenguaje para describir la relación entre imagen e interpretación: 'Quando sueña Rutuscam canique [Me cortaron el cabello], a de ser biuda' (Guaman Poma, 284); 'Puñuspa moçcoiñijquipi chacacta purispa, raquipacmi moçconi ñispa ñecchu canqui?' "Durmido en tu sueño, andando sobre un puente c sobre esto solías decir que soñaste para una separación?” (Pérez Bocanegra, 146, trad. del autor). Sus descripciones de interpretación de sueños son fragmentarias pero son las únicas disponibles de la colonia temprana en el Perú.

durante la revuelta. Las imágenes de sueño coreanas, como las quechuas, son tomadas de un léxico convencional pero son usadas como vehículos para integrar el sueño en un discurso de redención política-histórica.

16 Desafortunadamente, las fuentes coloniales sobre interpretación de sueños y augurios en los Andes no se pueden comparar en su riqueza y cantidad a sus equivalentes mesoamericanas. 
Algunos ejemplos de las imágenes de sueño en quechua surperuano.

\begin{tabular}{|ll|}
\hline Verde & Tristeza \\
Grasa de vaca o toro & Wayra (viento/alma) \\
Ebrios danzando en barro & Lluvia \\
Zapato viejo & Se mantendrá con la misma pareja \\
Burro & Buena suerte \\
Soga & Caminar a pie \\
Gato & El demonio \\
Taxi o auto privado & Ataud \\
Policía & Dios \\
Sed & El alma necesita alimento (confesión \\
& o misa) \\
Cebollas & Dolor, pena \\
\hline
\end{tabular}

Figura 2. (A partir de Mannheim 1987).

Ambas descripciones de interpretación de sueños se encuentran clasificadas dentro de prácticas culturales locales, no-cristianas. En España del s. XVI el conformismo cultural era identificado con ortodoxia religiosa. Varias prácticas que hoy en día consideramos como no-religiosas como el lenguaje, el estilo de vestir, prácticas sexuales y modales de mesa eran entendidos como signos externos de la identidad religiosa, y fueron regimentadas y vigiladas (Kamen 1985: 198-218; Root 1988: 125-26). En América, esta política llevó a los misioneros tempranos a buscar y identificar prácticas culturales locales que parecían ser contrapartes de heterodoxias europeas, o que amenazaban la nueva hegemonía religiosa cristiana. Las reprehensiones contra las idolatrías no solamente fueron campañas contra la religión indígena en un sentido estricto, sino fueron reprehensiones comprehensivas que iban en contra de cualquier índice de no ser un cristiano creyente. Los sermonarios, confesionarios y manuales para curas del s. XVI y XVII denunciaban la sodomía, el comer sentados en el piso, y la interpretación de sueños como 'idolátricos', junto con prácticas más claramente religiosas como la adoración a la tierra (Charles 2010: 74-76 y 97-101; Flores Ochoa 1972; Harrison 2014; Horswell 2005). La identificación de prácticas religiosas se extendía a identificar conceptos religiosos americanos con los del viejo mundo, como los cimin arahuaco (en el Caribe) y los wak'a peruanas fueron concebidos en términos del becerro de oro en la biblia hebrea (Cummins 2009; Mannheim \& Salas 2014; van de Guchte 1990: 242). La iglesia colonial estaba especialmente preocupada por los sueños porque en otras partes de América, la interpretación de los sueños era realizada por especialistas 
rituales; por lo tanto, su interpretación podría legitimar la autoridad de un sacerdocio nativo. Dado que la interpretaciones era hechas por laicos, este miedo era infundado. Es principalmente en las listas de prácticas religiosas nohegemónicas (pero no necesariamente contra-hegemónicas) que otras fuentes coloniales corroboran las descripciones de Guamán Poma y Pérez Bocanegra. Pero, a pesar que las prácticas interpretativas a nivel local permanecieron constantes desde la invasión europea, las imágenes de los sueños y sus interpretaciones han cambiado notablemente. Pérez Bocanegra proveyó un pequeño léxico de imágenes de sueño de la parroquia de Andahuaylillas. Por coincidencia, hice mi trabajo de campo en la misma parroquia a fines de 1970, y pude recolectar material directamente comparable al punto de haber sido recogido de los descendientes de los informantes de Pérez Bocanegra.17 (Otra fuente colonial para Andahuaylillas, de fines del s. XVIII, menciona interpretaciones de sueños pero no brinda información específica (Orcaín 1790)). En el siguiente cuadro comparo las imágenes de los sueños del texto de Pérez Bocanegra publicado en 1631 (completado en 1622) y las de mi trabajo etnográfico realizado en la misma parroquia 350 años después. Las imágenes de los sueños están listadas en la primera columna de la Figura 3, seguidas por las interpretaciones provenientes del s. XVII y las modernas. 's/i' indica que no hay interpretación contemporánea de la imagen a pesar de que traté de obtenerla reiteradamente. Asimismo, como la interpretación de sueños es un tema frecuente en las conversaciones matinales, 's/i' también significa con casi total certidumbre que la imagen ha sido perdida en la comunidad. El gran número de imágenes que no tienen interpretaciones contemporáneas puede crear la errónea impresión que el sistema de interpretación de sueños se ha desintegrado desde el s. XVII. Sin embargo, así como muchas imágenes se han perdido desde el s. XVII, muchas otras-el policía y el taxi por ejemplo-se han añadido.

A primera impresión, no es sorprendente que el léxico de sueños haya cambiado tanto en 350 años, especialmente si se consideran los cambios cataclísmicos que sufrieron las comunidades quechuas en ese periodo. Sin embargo, contrastar esto con una notable persistencia cultural que etnógrafos e historiadores han registrado en material iconográfico (Cereceda 1978b; Gisbert 1981; Hocquenghem 1987; López Baralt 1987), ritual, patrones de estructura social como la organización en mitades (Cereceda 1978a, Flores 1972, 1976; Hopkins 1982; Zuidema 1970), calendarios y cosmología (Isbell 1978:197-220; Ossio, ed. 1973; Urton 1981; Zuidema 2011) y mitología (Custred 1978, Ortiz 1973, 1978; Zuidema y Quispe 1968). La persistencia de formas culturales andinas

17 Evidencia interna en el manual para curas de Pérez Bocanegra indica que éste está basado en sus experiencias en Andahuaylillas (Mannheim 1991: cap. 6). 
es lo suficientemente amplia para haber proveído una heurística con la cual pueden ser identificadas la variación y los cambios en formas y prácticas simbólicas. Comparada con la persistencia de otros sistemas semióticos andinos, la inestabilidad de las imágenes de sueños es anómala. Si los cambios fueran simplemente una cuestión de erosión a través de 350 años, deberíamos encontrar cambios de una escala similar en otros sistemas semióticos. Sin embargo, esto no es lo que los etnógrafos e historiadores andinistas han observado. Estamos enfrentados con el problema de explicar por qué el léxico de sueños ha cambiado mucho más rápidamenwte que otros sistemas semióticos. Más ampliamente la pregunta sería ¿por qué algunos sistemas semióticos son más estables que otros? Y ¿por qué el correspondiente a la interpretación de los sueños es tan inestable?

\begin{tabular}{|c|c|c|}
\hline IMAGEN & 1631 & Hoy en día \\
\hline Cruzar un puente & Separación & Día afortunado \\
\hline Coger un pez & Suerte & $\begin{array}{l}\text { s/i (Interpretación } \\
\text { inexistente) }\end{array}$ \\
\hline Venado & Planes frustrados & $\mathrm{s} / \mathrm{i}$ \\
\hline Persona sin cabeza & \multirow{4}{*}{$\begin{array}{l}\text { Separación, desastre, demo- } \\
\text { nio, mal viento }\end{array}$} & $\mathrm{s} / \mathrm{i}$ \\
\hline Persona manca & & $\mathrm{s} / \mathrm{i}$ \\
\hline Serpiente & & $\begin{array}{l}\text { Acto sexual proble- } \\
\text { mático }\end{array}$ \\
\hline Perdiz & & $\mathrm{s} / \mathrm{i}$ \\
\hline $\begin{array}{l}\text { Cóndor (si un nacimiento } \\
\text { es inminente) }\end{array}$ & Nacimiento de un niño (varón) & $\begin{array}{l}\text { s/i, reemplazado por } \\
\text { 'comer naranja' }\end{array}$ \\
\hline Lana & Pena extrema & $\begin{array}{l}\text { s/i, reemplazado por } \\
\text { 'agua turbulenta' }\end{array}$ \\
\hline Tela de araña & Pena extrema & $\mathrm{s} / \mathrm{i}$ \\
\hline Planta de quinua leñosa & Ropa de luto & $\mathrm{s} / \mathrm{i}$ \\
\hline $\begin{array}{l}\text { Aparecer iluminado por el } \\
\text { sol o la luna }\end{array}$ & Muerte de un vecino & $\begin{array}{l}\text { Buena fortuna (oscu- } \\
\text { ridad es muerte) }\end{array}$ \\
\hline Pequeñas aves & Miedo & Miedo \\
\hline Persona oscura & \multirow{3}{*}{ Algún tipo de desastre } & $\mathrm{s} / \mathrm{i}$ \\
\hline Cerdo & & $\begin{array}{l}\text { Suq'a (hueso de } \\
\text { ancestro que causa } \\
\text { enfermedad doloro- } \\
\text { sa y muerte) }\end{array}$ \\
\hline Perro & & Robo \\
\hline Ropa nueva & Muerte & Muerte \\
\hline Viaje & Derrota & $\begin{array}{l}\text { Pérdida de una cita } \\
\text { o un compromiso }\end{array}$ \\
\hline Sapo, viento & Miedo & Brujería \\
\hline Serpiente bicéfala & Gran desastre & $\mathrm{s} / \mathrm{i}$ \\
\hline
\end{tabular}

Figura 3 (en base a Mannheim 1987) 


\section{La estructura semiótica de los sueños, la narrativa y el ritual}

Para responder estas preguntas necesitamos discutir la organización semiótica de la interpretación de sueños, y mostrar como su organización semiótica es distinta a la dos de los sistemas más estables: la narrativa y el ritual. De acuerdo con Peirce (1931[1997]) y Morris (1938, secciones 3, 5, 7), los signos tienen significado por virtud a tres relaciones primarias: (1) Las relaciones semánticas de los signos con sus objetos, por medio de otros signos (sus interpretantes); (2) las relaciones sintácticas de los signos con otros signos con los que están combinados; (3) las relaciones pragmáticas de los signos con sus usuarios18 (ver figura 4).
(1) semántica
signos
objetos
(2) sintáctica
signos
otros signos
(3) pragmática
signos
usuarios

\section{Figura 4}

Los significados de los signos, entonces, están determinados por estas tres dimensiones, que incluyen las relaciones entre signos y otros signos con los que están combinados (sintáctica), y las relaciones entre signos y sus usuarios (pragmática). Las tres dimensiones de semiosis - semántica, sintáctica y pragmática - están parcialmente especificadas en la estructura formal de una práctica cultural y parcialmente dadas por el proceso de interpretación. Hay una toma y daca entre la estructura formal y los procesos de interpretación. Cuanto más especifica es la estructura formal, menor es el juego en la interpretación. Y viceversa, cuando menos específica es la estructura formal para una de estas dimensiones, más es proveído por el proceso de interpretación. Los sistemas culturales (o sistemas semióticos) difieren en los grados en que sus tres dimensiones de semiósis estén formalmente especificadas. Por ejemplo, la música tiene dimensiones sintácticas y pragmáticas ricamente elaboradas, pero una dimensión semántica poco especificada.

En la medida que las dimensiones sintáctica y pragmática están presentes en la estructura formal de una acción, los significados de los signos están limitados por la estructura formal. En la medida que la estructura formal de una acción es especificada y persiste en el tiempo, los significados de los signos

18 Charles Sanders Peirce (1931[1897 2: 227-29) distingue "la lógica critica", "la gramática especulativa" y "la retórica", respectivamente, para estas tres dimensiones de semiósis. (Ver también Feibleman 1946: 85-88). 
están anclados, seguros en contextos estables.19 Así, la relativa estabilidad de un sistema de signos está establecida por el grado en el que las relaciones sintácticas y pragmáticas están directamente codificadas en las formas.

La interpretación de los sueños en quechua surperuano requiere que las imágenes de sueños sean extraídas de sus contextos sintácticos de las narraciones de sueños. Se los interpretan usando un léxico convencional e impersonal que también los extrae de sus contextos pragmáticos iniciales. Como consecuencia, los sueños tienen significados a través de una relación semántica inmediata entre imagen e interpretación. Ellos codifican la dimensión semántica y dejan sin especificar las relaciones sintácticas y pragmáticas. 20

En cambio, en la narrativa, las dimensiones sintácticas y semánticas están especificadas; los signos en la narrativa ocurren en secuencias preordenadas (Lévi-Strauss 1959; T. Turner 1969). En el quechua sureño, los signos de narrativa están empaquetados en pequeños módulos sintácticos de eventos. Estos módulos son combinados tanto por el narrador como por su audiencia en una realización narrativa (ver Allen 1986, 2011; Mannheim 1999; Mannheim \& van Vleet 2000).21 Explicaré estos puntos con resúmenes—sacados de los últimos dos artículos ya citados-de tres narrativas relacionadas.

Kunan Urcos llaqtapi, Urcos qucha kasyan. Kikin Urcos qucha panpa kasqa. Chay panpapi llank'aq kasqa huk runa inkarnasyun p'unchayta. Hinaspa unu llapanta apayapuq kasqa llank'aq turuntinta chay inkarnasyun p'unchayta llank'asqanmanta (Gow y Condori 1976:10).

19 Similarmente, el filosofo W.V.O. Quine (1960: 90ff.) sostiene que la forma gramatical delimita el rango de variabilidad del significado de una palabra. Esta observación de Quine ha sido confirmada experimentalmente por Taylor y Gelman (1988), quienes muestran que los niños usan evidencia sintáctica para identificar los significados de las palabras, arrancándolos conceptualmente de sí mismo por sus propios esfuerzos. Para un ejemplo sintáctico del Quechua, véase Mannheim \& Gelman (2013).

20 Cuando digo que algo está 'codificado', quiero decir que está especificado como parte de la estructura formal de una acción, y no que esto (necesariamente) codifica algo existente independientemente de la acción. (Agradezco a A.L. Becker por señalarme esta fuente de confusión).

21 Los folcloristas han usado tradicionalmente el término 'motivo' para identificar 'cualquiera de los elementos incluidos en un cuento tradicional' (Thompson 1950: 753), incluyendo caracteres, secuencias de acciones y circunstancias alrededor de las acciones. Uso la palabra 'módulo' en un sentido más restringido como secuencias de eventos que están marcadas por la organización formal de una realización narrativa, y que son recurrentes de narrativa en narrativa. Estos módulos reaparecen de narrativa en narrativa, estando ligados a un campo discursivo más amplio dentro del cual las narrativas especificas adquieren sus significados. El objetivo de un análisis modular es identificar las resonancias intertextuales a través de las cuales las realizaciones narrativas particulares son inteligibles para sus participantes. El análisis de motivos, por otro lado, ha sido usado principalmente como un criterio de clasificación. Véase Briggs \& Bauman (1996) para una discusión mas amplia de la intertextualidad en el análisis del arte verbal. 
La laguna de Urcos está en el actual pueblo de Urcos. La laguna misma era antes una pampa. Se dice que el día de Nuestra Señora de Encarnación un hombre estaba trabajando en ella. Entonces el agua arrastró todo, al labrador a su toro, por estar trabajando el día de Nuestra Señora de Encarnación.

Esta explicación del origen de la laguna de Urcos como un castigo divino ocurrió en una discusión más amplia acerca de la Madre Tierra (Pachamama), sus manifestaciones y su poder. Emerge de una narrativa árida frente a las preguntas de la antropóloga Rosalind Gow. La anécdota acerca de la laguna de Urcos carece de una relación clara con las descripciones que la preceden o continúan, con la excepción que la posición de esta anécdota sugiere que la inundación fue causada por la Madre Tierra como un castigo porque un hombre estaba trabajando durante la fiesta de Nuestra Señora de la Encarnación, considerada una manifestación de la Madre Tierra.

A inicios del s. XVII, el cronista nativo Santacruz Pachacuti Yamqui Salcamaygua (1613:f.4r-f.4v) describió cómo el dios Tonapa Uiracocha caminaba de pueblo en pueblo disfrazado como un viejo mendigo.22 Tonapa llegó al pueblo de Yamquisupa del cual fue expulsado. Tonapa maldijo a los habitantes del pueblo quienes fueron aniquilados por una inundación. Lo que alguna vez fue el pueblo de Yamquisupa es ahora la laguna Yamquisupa. En una montaña cercana está una roca que tiene forma de una mujer, también destrozada por Tunupa.

Esta narración, en la cual un anciano es despreciado y subsecuentemente transforma un pueblo políticamente importante en una laguna, es familiar a quechuahablantes contemporáneos. Aquí introduzco el resumen de la historia que me contó una persona que creció cerca de otra laguna surandina, la laguna de Piwiray en Chinchero (Urubamba, Cuzco):23

La laguna Piwiray antes no era laguna. Era la ciudad del Cuzco [el doble exacto de Cuzco, la antigua capital de los Inkas]. Un día había una gran fiesta de matrimonio en Cuzco. Realmente festejaban: tomaban y comían a satisfacción, y bailaban enérgicamente. Entonces, sin ninguna

22 Varios de los capítulos iniciales del manuscrito anónimo de Huarochirí (inicios del s. XVII) también describen a un vagabundo dios-héroe cultural-Huatyacuri-quien juzga a individuos y pueblos enteros, seduce a sus pobladores y repara sistemas de irrigación. Tanto este manuscrito anónimo como la crónica de Santacruz Pachacuti Yanqui estaban entre los papeles del sacerdote Francisco de Ávila, quien estaba especialmente preocupado en erradicar las prácticas religiosas de los nativos andinos.

23 La historia del origen de la laguna Piwiray me fue contada por la señora Rosalía Puma Escalante en una elicitación formal. Normalmente, los mitos Quechuas están inmersos en conversaciones cotidianas y son contados conversacionalmente. (Lo discuto en más detalle en Mannheim 1999 y en Mannheim y van Vleet 2000.) 
verguienza, un viejito entró a la casa de la fiesta. Estaba vestido con harapos, y tenía su cara sucia llena de moco y legañas.

Los celebrantes insultaron al viejo: "Boten a ese viejo. Como está asquerosamente vestido, le botaremos asquerosamente.” El viejo se alejó llorando amargamente.

Cuando se iba, una mujer se compadeció de él. [Seguro era una visitante.] Estaba indignada del comportamiento de los invitados. Fue tras él, llevándole comida y chicha de jora. El viejo ya había llegado a las montañas fuera de la ciudad. La mujer lo seguía sin poder alcanzarlo. Entonces gritó para que el viejo la esperara. El viejo le dijo que sin importar lo que pasara ella no debía voltearse y ver hacia atrás. Pero ella volteó y vio que toda la ciudad había sido convertida en una laguna. Sus parientes, su bebe, su marido; todos que eran alguien para ella estaban allá. Desesperada la mujer se volvió en piedra.

En este punto, la narradora sospechó que yo no había entendido que el viejo

era Dios, y que había acudido disfrazado para poner a prueba a quienes festejaban.

Ahora aquella ciudad del Cuzco (en oposición a la ciudad del Cuzco que todos conocemos) es una laguna, la laguna Piwiray. A medianoche puedes escuchar un gallo cantando dentro de la laguna y el repique de una campana. Si es que subes aquella montaña y observas dentro de la laguna, a medianoche puedes ver dos grandes toros dorados que brillan en el agua.

La asociación entre infracción social y destrucción por inundación o ser convertido en piedra es conocida a lo largo y ancho de los Andes (Allen 1988:65; Morote 1953: Ortiz 1973: cap. 4 y 6). En la primera historia, un campesino es castigado por trabajar en el día de una virgen, cuando debía haber estado festejando con sus vecinos, por lo que sus campos fueron inundados. En la segunda y tercera, grupos festejando cometen una de las peores ofensas morales concebibles en el mundo andino: expulsar a alguien de una festividad. En las dos últimas historias ciudades enteras sufren el castigo divino. La relación entre la ofensa social y moral, la imagen de la laguna y la destrucción por el agua están codificadas directamente en la sintaxis de la narración, proveyendo una cualidad perdurable a esta asociación que ha permitido tanto su persistencia en el tiempo-por lo menos desde el s. XVI-como su difusión a través de los Andes.

Para los andinos nativos, estas relaciones tienen características objetivas que van más allá de un grupo de asociaciones intelectuales abstractas. A pesar que la historia de la ciudad sumergida es conocida en todos los Andes, en ésta siempre se menciona una laguna local que es conocida tanto por el narrador 
como por la audiencia. Al inscribir el paisaje en la narrativa y su contenido moral implícito da a la narrativa un carácter objetivo que trasciende el aquí y ahora de la realización misma de contarla. Las historias inscritas en el paisaje son de acuerdo a los andinos nativos 'verdaderas' (chiqaq; Allen 1986).

Hasta este punto me he concentrado solamente en un solo módulo narrativo, en el cual una ofensa social y moral, la imagen de la laguna y el castigo por inundación están ligadas secuencialmente de tal forma que cada una ancla las otras. Las narraciones de inundaciones, por supuesto, son más complejas que una secuencia única. (Después de todo mi meta no es interpretar las narraciones sino subrayar cómo las secuencias narrativas anclan significados en lugares específicos.). Otros módulos en las narraciones de inundaciones los vinculan a un campo discursivo más amplio sobre hidráulica y género (v. Mannheim 1999). Consideren la siguiente narración sobre dos mujeres que se encontraron con sirenas que emergió en una entrevista etnográfica acerca del sistema de riego en la comunidad.24 Este estilo, en el cual la narración es construida conversacionalmente es mucho más común en quechua que los monólogos que presenté antes (Howard 1989, 2012; Mannheim y van Vleet 2000). Esta y otras características de la realización narrativa están omitidas del resumen que sigue:

Cipriana y su hija Helena estaban conversando sobre un canal de irrigación que pasa por Qaqa Ñan. 25

Hay una sirena en Qaqa Ñan. Un día cuando estábamos yendo allí a regar nuestras chacras nos dimos cuenta que una inmensa mujer, ancha como un bulto tapado, estaba sentada en una piedra. 'Quizás ella venga hacia nosotros,' dijimos y, nos alejamos tan silenciosamente como un adobe todavía mojado. Ella se quedó allí y, nosotros ya no volteamos a mirar. La vimos a la luz de la luna, grande como un bulto, envuelta en un mantón negro, sentada en una piedra. Era hermosa y delgada, con aretes parecidos a los que la antropóloga está usando. Tenía un perro lanudo frente a ella.

Helena, la hija, dijo que ella vio una sirena a la luz de la luna. Era de la talla de una pequeña niña que estaba cerca de la entrevista. Se acercó a la sirena, pensando que era su amiga Santusita. La llamó y también le tiró algunas piedras para obtener su atención. Cuando se acercó más, la sirena saltó en el agua. Helena estaba aterrorizada y escapó.

24 La historia de la sirena le fue contada a Diane Hopkins durante una entrevista en la comunidad de Siqsinqalla en Andahuaylillas (Quispicanchi, Cuzco). Agradezco a la Dra. Hopkins por discutir conmigo su interpretación de esta narración y de las narraciones de inundación. La relación entre hidráulica y género en estas narraciones es tema de un manuscrito sin publicar de la Dra. Hopkins, sobre el que he elaborado mi análisis.

25 Helena y Cipriana son pseudónimos. 
De noche cuando pasas por Qaqa Nan donde se encuentra la sirena, puedes escuchar tambores y una banda de músicos. Es justo debajo de una de nuestras chacras. Cuando venimos por ese camino, borrachos y, escuchamos los tambores y la banda no nos importa porque estamos borrachos. Después de todo ¿eres una persona o un perro? Nosotros decimos solamente. 'iCarajo! ija!'

Sin embargo, todos asienten que Qaqa Ñan es un lugar feo, y da miedo. Es un lugar que es mejor evitar.

A pesar del estilo de narración, los personajes, y la naturaleza de la interacción social en la narración de la sirena son diferentes de las tres narraciones de inundación. Pero, hay relaciones formales claras que ligan éstas tres con la última narración en un campo discursivo más amplio que relaciona la hidráulica y el género (Mannheim 1999: 89-91). Me limitaré sólo a listarlas: El principal protagonista de las tres primeras es un ser sobrenatural masculino que desencadena el poder destructivo del agua mientras que las mujeres protagonistas de la narración de la sirena han regado sus chacras exitosamente-y asegurado su productividad cuando se encuentran con un ser supernatural femenino: sirenas que encarnan la unión de la tierra y el agua. En las tres primeras los humanos niegan sociabilidad al ser sobrenatural mientras que en la de la sirena los humanos ofrecen sociabilidad y son rechazados por el ser sobrenatural. En el episodio de la inundación en el cual una mujer es convertida en piedra ocurre en un camino que lleva desde el centro poblado hacia las alturas. En el de la sirena el episodio final explica que los lugares gritan (waqay) a media noche o en el crepúsculo: un gallo canta o una banda toca. Estos episodios son inexplicables, excepto como maneras de marcar cierta peligrosidad de estos lugares, o la vinculación de estas narrativas. Todo esto es sabrosamente LéviStraussiano; lo explico detenidamente en otro artículo (Mannheim 1999). Lo central aquí es que el significado de cada signo narrativo está anclado en un lugar por su posición sintáctica en la narrativa, y por la posición de la narrativa en un campo discursivo mayor.26

En el ritual, la relación pragmática entre los signos y los participantes es también especificada. Los rituales especifican acciones en secuencias invariables. De esta forma también especifican las relaciones entre los participantes en un ritual y los signos que lo constituyen. Como Víctor Turner mostró en su exquisito análisis del ritual, los significados de los signos rituales no sólo están delimitados semánticamente sino también posicionalmente en relación

26 No es de interés aquí el que la polaridad moral y las imágenes en estas narrativas sean también temas familiares en tradiciones occidentales. Los alineamientos morales y las configuraciones de imágenes y eventos en estas historias son completamente andinos, a pesar de las fuentes de personajes e imágenes individuales. 
con otros signos, y operacionalmente en relación con sus usuarios (Turner 1968:17, 81ff., 1973; Rappaport 1976:80ff.; Moore y Meyerhoff 1977:7-8; Tambiah 1985[1981]:145-153).27 Los participantes de un ritual lo viven a través de sus cuerpos. Este rasgo del ritual es crítico para su potencial transformador de la conciencia de sus participantes (Lienhardt 1961; Ortner 1978:5-9; Whitehead 1987). No repito aquí la idea anticuada que propone que el ritual dice en acciones lo que el mito dice en palabras. Toda narrativa oral tiene un fuerte componente no verbal, incluyendo convenciones que gobiernan la interacción de los participantes, tanto como cualquier ritual incorpora componentes verbales o silencios significativos.28 La realización ritual es distinta de la mítica pues el objeto específico del ritual es la acción, y un conjunto específico de acciones son rasgos fundamentales de todo ritual.

He aquí un ejemplo. En el día de San Juan, 24 de junio, campesinos y ganaderos de los andes sur centrales realizan rituales domésticos para la fertilidad de sus animales, especialmente sus ovejas (Allen 1988:165-168; Contreras 1985: 114-116; Cuba 1971; Paz 1971; Vivanco 1971).29 En la comunidad de Lluthu (Andahuaylillas, Cuzco) los animales son manejados por una mujer y sus hijos adultos, quienes participan en los rituales del día de San Juan. El esposo de la mujer mayor participa, pero ninguno de los esposos o las esposas de sus hijos lo hacen.

Los rituales tienen dos componentes principales: se hace una fogata de paja y ramas durante la noche del 23 de junio y se realiza una ofrenda de alcohol para los animales. El fuego humeante, la ofrenda al corral de la casa y a los dioses-cerros es cuidado por el esposo de la mujer mayor. A lo largo de la noche él permanece sentado cerca de la casa, dando la frente hacia el corral y las faldas de la montaña. En la mañana los hijos e hijas arriban y tomando turnos hacen ofrendas de alcohol a los animales, primero a las ovejas y luego a las vacas.

En pares de dos, un hombre y una mujer, llenan calabazas con una bebida hecha de maíz (a base de chicha de jora). Se arrodillan en el corral, el hombre a la izquierda y la mujer a la derecha, mirando hacia las ovejas. Toman un poco de tierra con la mano derecha y la besan. [foto1] (Como pueden imaginar

27 Ver Custred (1979: 384-386) para una discusión de los significados posicionales de los símbolos rituales en las ofrendas a la tierra.

28 La actuación (o la realización) en la narrativa son discutidas por D. Tedlock (1985[1971]), Barman (1975), y Basso (1985).

29 Los rituales descritos aquí están relacionados estrechamente a otros dos grupos de rituales para la fertilidad animal que se llevan a cabo a medios o fines de agosto y durante la fiesta cristiana de carnavales (Alencastre Gutiérrez y Dumézil 1953; Flannery, Marcus y Renolds 1989: 143-82; Isbell 1978: 151-63; Quispe 1969). 
la tierra de un corral se encuentra llena de estiércol.) Dejan cuidadosamente la tierra y levantan los mates también con la derecha. Se paran y esparcen la chicha sobre las ovejas. [fotos 2y 3] Si una oveja se acerca hacia el jarro de chicha, se le fuerza a tomar licor. El mismo procedimiento se hace para las vacas. Esta vez las posiciones son invertidas, la mujer se ubica a la izquierda del hombre.

Cada uno de estos gestos reafirma la relación de reciprocidad que los dueños de los animales mantienen con la tierra, los dioses-cerros, el corral y los animales, una relación que asegura la fertilidad y bienestar de los animales y la prosperidad del hogar. La fogata durante la madrugada del día de San Juan es una ofrenda a la tierra y al corral; la chicha es una ofrenda a los animales. Cada gesto está inscrito en un conjunto de relaciones espaciales entre participantes y destinatarios de las ofrendas. Lo roles participativos son fijados espacialmente por el ritual, y ellos a su vez fijan los significados de los símbolos y gestos individuales del ritual. Más allá de la ropa y algunos bienes materiales, y aparte de que estos ritos son efectuados en la fiesta de un santo católico, estas acciones rituales habrían sido inmediatamente reconocidas por quechuas precolombinos.

Aquí expongo otro ejemplo, esta vez una imagen ritual singular. En los ritos para la fertilidad animal como los del día de San Juan y otros rituales similares llevados a cabo en coincidencia con la fiesta católica del carnaval, los agricultores y pastores quechuas del sur del Perú usan las flores llamadas phallcha (Gentiana luteomarginata y sus variedades) en distintas formas: las echan sobre los animales en el corral familiar, adornan con ellas a los animales, tiñen con ellas el licor ofrecidos a los animales y las utilizan para hacer confeti.30 (En algunos lugares el carnaval es conocido como Phallchasqa, 'phallchascado!' (Salas Carreño 2015; Webster 1972: 188-94; cf. Herrera 1938: 58). Estos ritos reafirman la posición de los humanos en un sistema de intercambios recíprocos de substancias, nutrición, y control de la fertilidad con los dioses-cerros, la tierra, los cultivos y los animales domésticos. Las flores de phallcha son recogidas en abras entre montañas y ofrecidas a los animales, ellas median muchas de estas relaciones y vienen a incorporar la fecundidad así como el poder de los dioses-montaña para regular la fertilidad. La asociación entre la flor phallcha y la fecundidad se establece como índice cultural por la acción ritual en la cual son usadas. Una vez establecida esta asociación indéxica, se está esparcida en otros contextos.

30 El botánico Fortunato Herrera $(1938: 55-6,58)$ identificó como phallcha cuatro especies de genciana a las que se les da los mismos usos rituales: gentiana scarletina, gentiana primuloides, gentiana sandienses, y gentiana campanuliformisis. Webster (1972:189) menciona que flores rojas y amarillas son usadas en carnaval en Q'eros (cf. Lira 1944: 802-3). Para una discusión sobre phallcha y sus usos por los quechuas sur peruanos ver Franquemont (1988: 179-80). 
Estas acciones asientan el significado de la phallcha en el tiempo. En un himno en quechua a la Virgen María compuesto a inicios del s. XVII por Juan Pérez Bocanegra-el mismo sacerdote que recopilo las imágenes de sueños-María es alabada por su fecundidad como progenitora del paraíso e invocada con imágenes de fertilidad celestial y terrena: Pucai-pucai çumac pallcha, 'Enrojece, enrojece, bella flor de phallcha' (Pérez Bocanegra 1631; Mannheim 2000). A pesar que el autor era un sacerdote católico, utilizó imágenes religiosas quechuas con el fin de hacer el catolicismo accesible a los nativos andinos (Mannheim 2000). En una canción moderna que contrapone prácticas religiosas andinas y cristianas, la flor de phallcha es esparcida a los pies del niño Jesús (Mannheim 2000). Actualmente la phallcha continúa representando la fecundidad. Los pastores de Q'ero (Paucartambo, Cuzco) cantan en sus phallchasqa, ¿Pi manan yuyariq phallchayuq? ¿Quien sin recordar su phallcha puede estar? (Cohen 1984; 2002-trad. del autor, de una copia magnetofónica).

La canción es cantada por una persona en una realización singular, pero la memoria cultural no está contenida en signos individuales sino en conjuntos relacionales-signos con otros signos, signos con sus usuarios. El secreto de la persistencia de la flor phallcha como una representación de la fecundidad se explica por los contextos sintácticos y pragmáticos más amplios en los cuales es usada. Como otros signos rituales, el significado de phallcha está anclado por relaciones sintácticas y pragmáticas recurrentes, codificadas, que lo ligan con otros signos y con acciones rituales específicas.

Retornaré aquí a nuestra pregunta más amplia: ¿por qué la narrativa y los signos rituales quechuas persisten en el tiempo mucho más consistentemente que los signos de sueños? Ambos, la narrativa y el ritual estipulan relaciones sintácticas secuenciales entre signos. Adicionalmente, el ritual especifica relaciones pragmáticas entre signos y sus usuarios. Estas relaciones sintácticas y pragmáticas codificadas anclan signos a sus contextos y actúan como limitantes de la interpretación semántica de estos signos, y de esta manera estabilizan sus significados a través de las poblaciones y a través del tiempo. Esto explica la persistencia simbólica observada por innumerables investigadores del ritual y la mitología andinas.

En contraste, la interpretación de sueños en el quechua surperuano supone descontextualizar las imágenes de toda secuencia narrativa o contexto pragmático. Esto es logrado tanto al seleccionar imágenes individuales en el proceso de interpretación o por suprimir todo el sueño excepto una sola imagen convencional. Debido a que las imágenes de sueños son interpretadas primariamente a través de relaciones semánticas inmediatas y no dentro de matrices sintácticas y pragmáticas codificadas, imagen e interpretación son 
menos resistentes al cambio que los signos de la narrativa o el ritual. Debido a la naturaleza de la interpretación de sueños, las características semióticas que explican la persistencia de los signos del ritual y la narrativa están ausentes en la interpretación de sueños. La relativa fluidez de los signos de sueños es determinada por la forma en la cual estos son interpretados.

\section{Soñando sin teorías}

Anteriormente, observé que la estructura de interpretación de sueños es necesaria - pero no suficiente - para explicar la fluidez de los signos de sueños. Es igualmente importante la ausencia de otras prácticas simbólicas que puedan estabilizar los signos de sueños. La literatura etnográfica en interpretación de sueños sugiere una posible fuente de estabilidad: Muchos estudios etnográficos de sueños toman las teorías nativas de sueños como sus puntos de partida para construir un equivalente nativo de las prácticas interpretativas occidentales. Estas teorías nativas también funcionan como dispositivos limitantes culturales. Ellas no sólo comunican ideas nativas acerca del soñar como actividad sino también regimentan las prácticas del soñar y de interpretar los sueños. Teorizar el soñar es al mismo tiempo representarlo como un objeto intelectual e inculcar un esquema particular para entender cómo los sueños deben ser entendidos. Las teorías del soñar son inherentemente conservadoras, autorizando ciertas prácticas e interpretaciones y dejando de lado otras.

Entonces para entender la fluidez de los signos oníricos en el quechua surperuano, es también necesario conocer que los quechuas surperuanos no tienen una tradición de teorizar sobre la interpretación de sueños. A diferencia de otras culturas como la de los antiguos griegos, los contemporáneos mayas, los iroqueses, los argentinos y los norteamericanos que han desarrollado ricas tradiciones de reflexionar sobre la naturaleza de soñar, los quechuas surperuanos tienen poco interés en el soñar como un problema teórico. Es posible obtener respuestas nativas a preguntas directas sobre la naturaleza del soñar, como por ejemplo que el alma vagabundea en la noche. Pero éstas no tienen un estatus cultural especial, son sólo intentos individuales de ayudar a un etnógrafo a encontrar una respuesta a una pregunta, que ordinariamente no emergería en una conversación cotidiana en el quechua surperuano. No hay un conjunto fijo de representaciones culturales sobre la interpretación de sueños que el etnógrafo pueda usar para establecer la relevancia de cierto detalle de campo.31

31 Para una discusión mas amplia de este punto ver Andrade 2005, epílogo. Concuerdo con Andrade que se pueda extraer una etiología del sueño andino por un análisis formal de la manera de contarlo y que en este sentido sí hay una teoría tacita; el punto principal, sin embargo es 
Haciendo una digresión momentánea, la ausencia de una tradición nativa de teorizar el soñar establece límites al análisis etnográfico. En antropología cultural, es costumbre comenzar con una descripción típica de las creencias y conocimientos nativos para situar mejor el detalle etnográfico que sigue. Esto es perfectamente sensato; ¿de qué otra forma un etnógrafo podría decidir cuales de una infinidad de eventos y detalles debe observar, registrar y analizar? Si hubiera seguido esta estrategia interpretativa acostumbrada, hubiera empezado mi texto con un conjunto de generalizaciones nativas acerca de los sueños. Después quizás hubiera mostrado cómo eventos aparentemente confusos (por ejemplo, el uso estratégico de sueños para negociar problemas sociales especialmente difíciles) son realmente consistentes con un conjunto de generalizaciones más amplio. En su lugar empecé este texto con sueños particulares, soñados por individuos particulares, en situaciones particulares, y de allí intenté mostrar la lógica interna del soñar como una práctica semiótica. Cuando trabajaba en este análisis, no era consciente de cuánto me estaba alejando de este camino ya establecido; pues simplemente no existían de tipificaciones nativas de creencias con las cuales pudiera calibrar los eventos a describir o examinar su consistencia. Intentaré poner algunos limites históricos y etnográficos a estas observaciones, para luego explorar como pueden estos estar presentes en otros aspectos de la cultura quechua surperuana.

En primer lugar, a pesar que la interpretación moderna de sueños de los quechuas surperuanos es llevada a cabo por no especialistas, disponemos de alguna evidencia histórica que sus ancestros Inkas, quienes manejaban un estado complejo y altamente organizado, mantenían una clase de especialistas en interpretación de sueños.32 Reportes de las campañas de extirpación de las religiones nativas de inicios del $\mathbf{s}$. XVII mencionan intérpretes de sueños (que daba respuesta de los sueños; moscoc 'el que sueña') y ministras de sueños (ministra soñadora) (Hernández Príncipe 1923[1622]: 25ff.; Arriaga 1968[1621]: 206; ver Curatola 2009: 14 y sig.; Jiménez 1961). La crónicas españolas tempranas sobre el estado Inka (p.e. Cieza 1967[1550]: 102) mencionan a especialistas en sueños e interpretes que dependían del estado. Garcilaso de la Vega (1609: lib. IV, cap. xxii) menciona que los sueños de la nobleza y los de los sacerdotes eran especialmente valorados como augurios.

que no existe teorías explícitas (Andrade 2005: 158-160).

32 Joseph Bastien (1987: 44) menciona que un curandero Kallawaya con el cual trabajó usaba la interpretación de sueños como un método de adivinación. Sin embargo, las prácticas de este curandero no diferían de la interpretación de sueños ordinaria en los Andes que no requiere conocimiento especializado. 
Estos reportes sobre especialistas estatales de sueños son plausibles, especialmente porque los augurios en sueños figuran en la mitología dinástica Inka (Jiménez 1961:89-90). En el fragmento del drama quechua citado al inicio de este texto, el último Inka, Atawallpa consulta al sumo sacerdote, a quien llama puñuq, 'el que duerme', a soñar por él para producir augurios. Pero es posible que las crónicas coloniales exageren el grado en el cual los especialistas eran consultados fuera del contexto del estado. Particularmente desde el s. XVI los españoles sospechaban de cualquier practica cultural que no estuviera específicamente sancionada por la Iglesia Católica. A pesar de que estas fuentes proveen una evidencia sobre la existencia de intérpretes especialistas mantenidos por el estado, no se menciona nada que nos indique alguna posibilidad de existencia de una ideología formulada explícitamente sobre el soñar y la interpretación de sueños, aún dentro del contexto de la administración estatal Inka. Quizás las teorías del soñar fueron parte de un conocimiento que se perdió con la caída del estado Inka. No tenemos evidencia disponible para el caso.

En segundo lugar, a pesar que los quechuas surperuanos no tienen formuladas teorías explicitas sobre el soñar, hablantes de otros lenguajes quechuas, genéticamente relacionados al quechua surperuano las tienen. Por ejemplo, los quichuas de la amazonía ecuatoriana tienen teorías sobre el soñar altamente desarrolladas y ampliamente compartidas, incluyendo ideas explícitas acerca de la agencia individual de quienes aparecen en sueños de otras personas o de aquellos que sueñan (ver MacDonald 1979; Kohn 2007:12, 2014: 110 y sig). En contraste con sus parientes quechuas surperuanos, los quichuas de la amazonia ecuatoriana manipulan activamente sus sueños como mecanismos para intervenir en disputas y otras actividades sociales. Ellos atribuyen a los eventos de los sueños tanta facticidad como a sus experiencias cuando están despiertos. El control exegético del soñar es consistente con otros aspectos de la cultura verbal de la amazonia ecuatoriana, particularmente con la rica exégesis del arte material y otras formas simbólicas (Whitten y Whitten 1988: 13).

De forma similar, en el caso de los hablantes de quechua surperuano, la ausencia de representaciones explícitas y conscientes y teorías de interpretación de sueños es consistente con otros aspectos de su cultura, tanto colonial como moderna. Los quechuas surperuanos, además de no hablar sobre lo que dicen del soñar, generalmente no hablan acerca del hablar (excepto para evaluarlo), y no discuten sobre formas y significados culturales en una manera explícita y consciente en términos que un etnógrafo pudiera reconocer. En la interacción cotidiana los quechuas surperuanos no producen interpretaciones verbales de formas o prácticas culturales. El conocimiento cultural es adquirido y está organizado sobretodo a través de la experiencia directa antes que por 
metacognición (Mannheim 1986). Este es un dato sociológico (más no cognitivo) y trae consecuencias importantes para la sociología del conocimiento. Las convenciones culturales entre individuos no están coordinadas a través del metalenguaje. Más aun, ningún sector de su sociedad tiene el privilegio de producir interpretaciones 'autorizadas' de prácticas sociales para la comunidad de hablantes.33 Un discurso exegético autorizado podría ser usado para estabilizar un sistema de interpretaciones. Correspondientemente, la ausencia de un discurso exegético autorizado permite-pero no garantiza-fluidez.

Puede parecer sorprendente que los quechuas surperuanos y los quichuas de la amazonia ecuatoriana, quienes hablan lenguajes genéticamente relacionados y han derivado mucho de sus repertorios simbólicos de una misma fuente, difieran tan radicalmente en sus formas de hablar sobre el soñar y usarlo como practica social. El que estas diferencias sean consistentes con otros aspectos de sus respectivas culturas verbales sugiere que algo sistemático está en juego, no solamente una presencia o ausencia de una tradición de teorizar sobre el soñar. Una 'comparación controlada' (en el sentido de Eggan 1954) de estas dos culturas verbales empezaría a iluminar las interdependencias entre formas en las que está organizado el hablar y en las que los sueños son soñados.

He propuesto que, en la cultura quechua surperuana, la relativa fluidez de los signos de sueños comparados con los signos del ritual y de la narrativa está determinada por la estructura de la interpretación de sueños. Es particularmente importante la manera de descontextualizar imágenes individuales de una narrativa del sueño e interpretarlas aisladamente unas de otras. Consecuentemente, las imágenes e interpretaciones de sueños son desligadas de sus matrices sintácticas y pragmáticas que normalmente estabilizan significados

33 Putnam (1975) señala que las comunidades de habla están sujetas normalmente a una división de trabajo sociolinguiístico, en la cual algunos de sus miembros tienen autoridad institucionalizada para determinar cómo la comunidad debe usar ciertas palabras. Por ejemplo, a pesar de que todos los hablantes de español usan la palabra 'oro,' se deja a ciertos hablantes-los joyeros por ejemplo-decidir qué cuenta exactamente como 'oro'. Otros miembros de la comunidad aceptan-tácita o explícitamente-esta autoridad. La autoridad social para determinar bajo qué condiciones el uso de una palabra o palabras es apropiado está cargada de autoridad política, especialmente cuando las palabras en cuestión tienen resonancias morales y políticas cruciales para la sociedad, tales como 'liberación', 'pecado', 'democracia', 'clase', 'feminidad', 'pueblo', o 'apropiado'. Los quechuas surperuanos también tienen una división de trabajo sociolinguístico: el conocimiento linguiístico y cultural está distribuido desigualmente en la comunidad de habla, de una forma no aleatoria y socialmente significativa. Pero esta desigual distribución de conocimiento no lleva el mismo tipo de peso moral, político y social que el correspondiente en las sociedades euro-americanas. 
culturales. Pero también juega un rol esencial en esta explicación el que la cultura quechua surperuana no disponga de discursos exegéticos o metalinguiísticos que estabilicen imagen e interpretación de una manera explícita y consciente para sus usuarios. Este es un problema fundamental en sí, y en el futuro será importante estudiar sistemáticamente por qué es así en diversos aspectos como: las formas en las cuales la ausencia de una tradición exegética consciente está vinculada a formas de autoridad en la vida cotidiana, a discursos epistemológicos nativos, a la estructura de participación en la interacción cotidiana, a formas de consciencia social (aunque no respecto a su presencia o ausencia) y a las tecnologías del poder y autoridad en la cultura quechua surperuana contemporánea.

\section{Apéndice: Tres tipos de cambio conceptual}

En su estudio de niveles jerárquicos de habla en javanés, Joseph Errington $(1985,1988)$ sostiene que los elementos linguísticos que están mas integrados pragmáticamente, los deícticos, sufren un cambio más rápido que otros elementos que están menos integrados a la situación del habla. Los deícticos, como pronombres personales, están implicados en la definición social de la persona y su reproducción en interacciones cotidianas. Cuando el campo institucional para la definición de la persona como un actor social cambia, el uso de elementos deícticos se altera también. Los deícticos en si mismos son una arena social en la cual las relaciones jerárquicas son desplegadas y negociadas (ver Friedrich 1978[1966]). Entonces, los elementos linguiísticos que especifican la dimensión pragmática están más fuertemente sujetos a cambio.

Lo encontrado por Errington puede ser reconciliado con lo que yo presento al distinguir tres tipos de cambio conceptual o cognitivo: (1) cambio dirigido por la indeterminación; (2) cambio dirigido por patrones; y (3) cambio dirigido pragmáticamente.

Los cambios dirigidos por indeterminación ocurren porque los actores sociales no necesitan compartir las mismas representaciones conceptuales para interactuar exitosamente. Aun para las formas más sencillas de hablar o de acción social, hay una considerable indeterminación en las maneras en las cuales los actores representan estas conceptualmente (cf. Quine 1960; Wallace 1961: 21-44). Los cambios dirigidos por indeterminación son limitados por los contextos sintácticos y pragmáticos en los cuales ocurren. Los cambios que he discutido en este artículo son ejemplos de esto. 
Los cambios dirigidos por patrones son motivados por una estructura más amplia en la cual un rasgo o práctica cultural ocurre, esto es la 'ramificación de un elemento cultural en la totalidad cultural' (Sapir 1949[1916]: 407; ver Sapir 1921: 157-182). El aspecto fundamental en el cambio dirigido por patrones es que los elementos linguiísticos y culturales están constreñidos por estructuras más amplias y abarcadoras, como los patrones culturales formales, tecnologías y prácticas discursivas. Los cambios pueden estar motivados o limitados por patrones más abarcantes. Por ejemplo, la pérdida de distinción entre los pronombres relativos who y whom en el inglés moderno se debe a la ausencia de una distinción entre casos nominativos y de objeto en la mayoría de los sustantivos en inglés y en todos los pronombres relativos (Sapir 1921: 16672). La pérdida de distinción entre who y whom sigue un patrón predecible. Similarmente, en los últimos quinientos años el quechua surperuano ha atravesado por una serie de cambios fonológicos que han erosionado distinciones entre consonantes al final de las sílabas (Mannheim 1991). Estos cambios han seguido un curso ordenado, en parte condicionados por factores fonéticos, morfológicos y sintácticos, pero expresados en términos de patrones fonológicos más amplios.

Los cambios dirigidos pragmáticamente están motivados por características específicas de las interacciones sociales en las cuales un aspecto cultural o linguiístico es usado. Estas características incluyen cambios en la definición de los participantes como actores sociales, en el sistema de clases y en los contextos institucionales de interacción. Los cambios dirigidos pragmáticamente tienden a corresponder directamente con otras formas de transformación social, ambos reflejos y fuentes de estos cambios. La emergencia del pronombre de la segunda persona del plural (e.g. vy, vous) para indicar reconocimiento de poder en los inicios de la Europa moderna (Brown y Gilman 1960) es un ejemplo de un cambio guiado pragmáticamente.

Toda instancia de cambio incluye los tres tipos aunque en diferentes magnitudes y formas. Los cambios en los niveles de habla del javanés discutidos por Errington son principalmente guiados pragmáticamente, los cambio en las imágenes de sueños del quechua surperuano son principalmente guiados por indeterminación. 


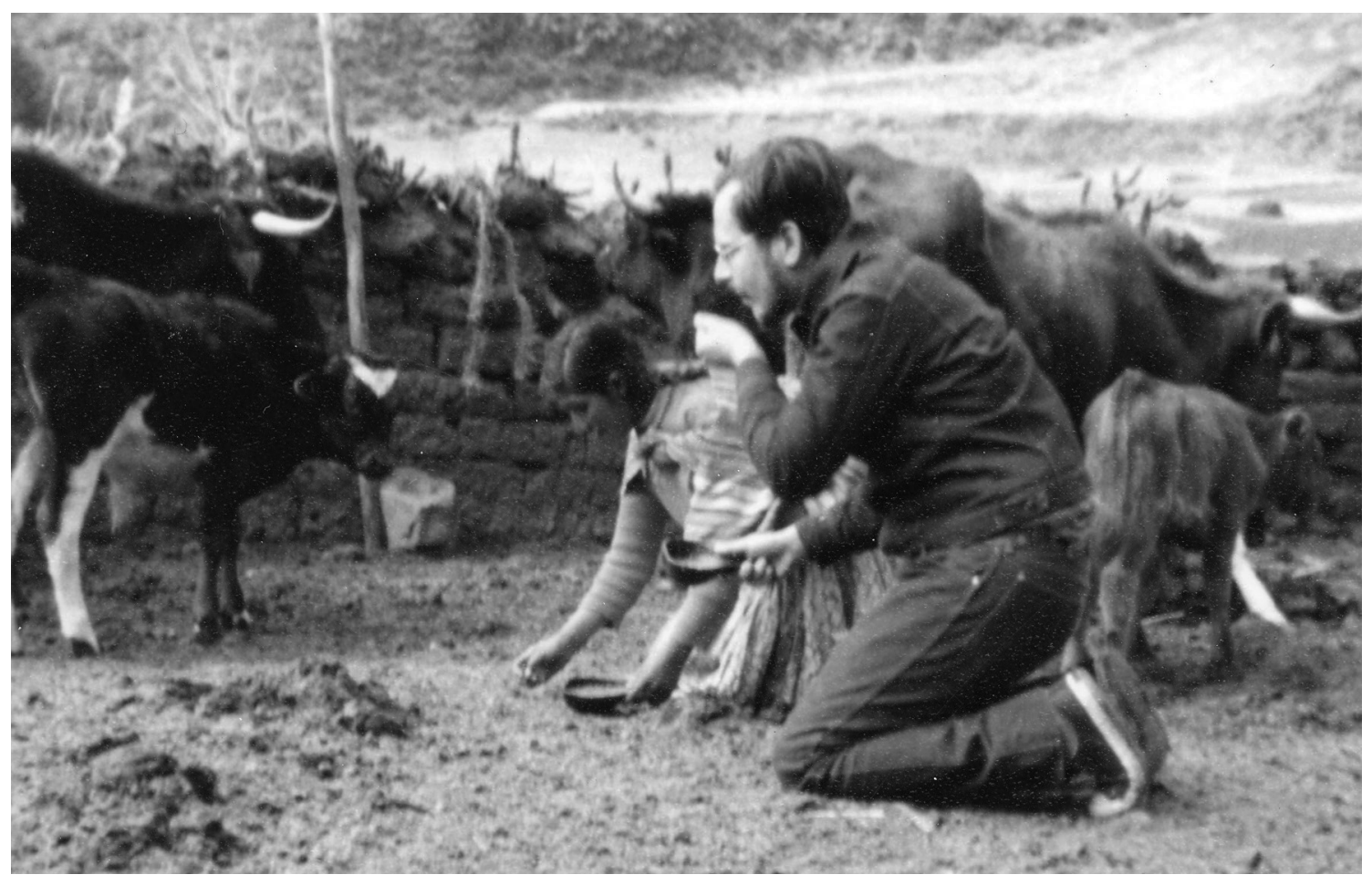

Foto 1 Besando la tierra en el coral

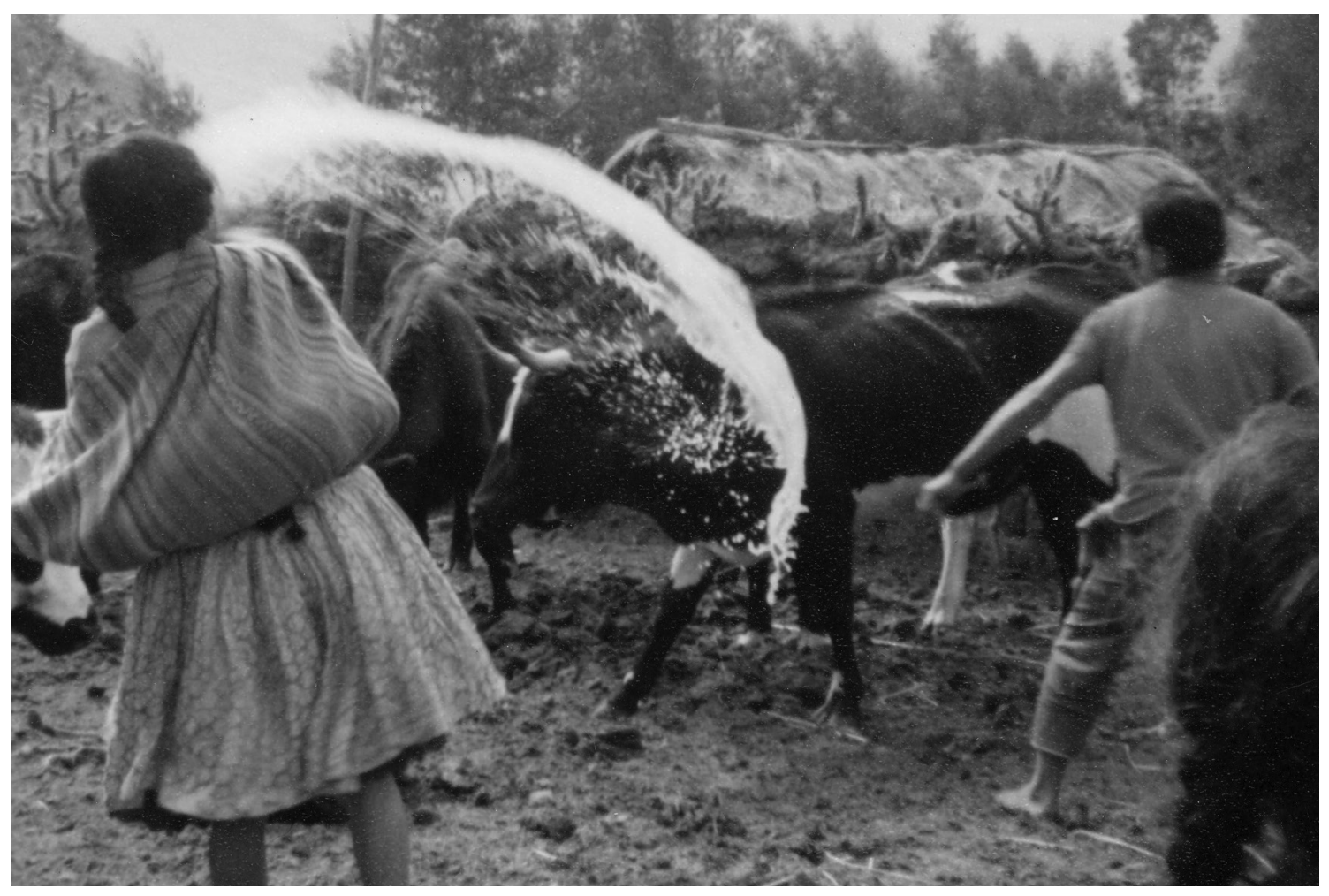

Foto 2 Esparcen la chicha sobre las ovejas 


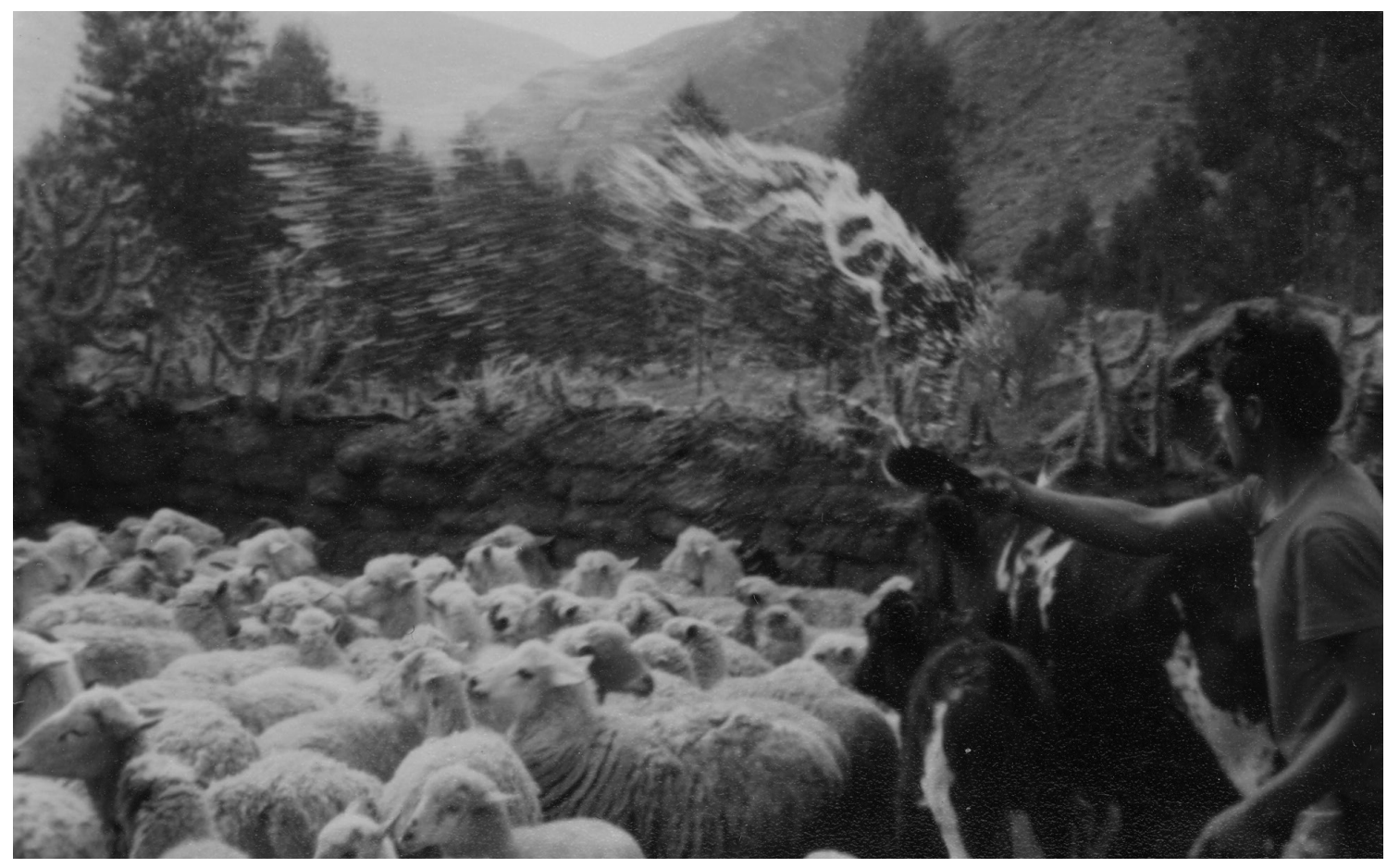

Foto 3 Esparcen la chicha sobre las ovejas

\section{Referencias bibliográficas}

ACKERMAN, Raquel (1985). Muleteers of the mountain gods: Eschatology and social life in a south central Andean community. Tesis doctoral en antropología social, King's College, Cambridge.

ALENCASTRE GUTIÉRREZ, Andrés y George DUMÉZIL (1953). Fêtes et usages des indiens de Langui (province de Canas, Département du Cuzco). Journal de la Société des Américanistes 42: 1-118.

ALLEN, Catherine J. (1986). Verbal bricolage: Sequencing of episodes in Quechua narrative. Ponencia presentada al la reunión de la American Anthropological Association. (1988). The hold that life has. Washington: Smithsonian Institution Press. (2011). Foxboy. Austin: University of Texas Press.

ANDRADE CIUDAD, Luis (2005) Aguas turbias, aguas cristalitas. El mundo de los sueños en los Andes surcentrales. Lima: Fondo Editorial de la Pontificia Universidad Católica del Perú.

ANONYMOUS - HUAROCHIRI (n.d. s. XVII) Runa yn[di]o niscap Machoncuna ñaupa pacha... manuscript 3169, ff. 64R 114R, Biblioteca Nacional, Madrid. En: (1987) Ritos y tradiciones de Huarochirí del siglo XVII, ed. Gerald Taylor. Lima: Instituto de Estudios Peruanos \& Institut Français d'Études Andines.

ARRIAGA, Pablo Jose de (1968) [1621] "Extirpación de la idolatría en el Perú" en Francisco Esteve Barba (ed.), Crónicas peruanas de interés indígena. Madrid: Biblioteca de Autores Españoles 209; pp. 191-207. 
BASSO, Ellen B. (1985) A musical view of the universe. Philadelphia: University of Pennsylvania Press.

BASSO, Ellen B. (1987) "The implications of a 'progressive' theory of dreaming”. En Barbara Tedlock (ed.), Dreaming, anthropological and psychological approaches. Cambridge: University Press; pp. 86-104.

BASTIEN, Joseph W. (1987) Healers of the Andes: Kallawaya herbalists and their medicinal plants. Salt Lake City: University of Utah Press.

BAUMAN, Richard (1975) "Verbal art as performance" en American Anthropologist 77; pp. 290-311.

BRIGGS, Charles L. \& Richard BAUMAN (1996) "Género, Intertextualidad y poder social" en Revista de Investigaciones Folklóricas, 11; pp. 78-108.

BROWN, Roger and A. GILMAN (1960) "The pronouns of power and solidarity” en Thomas A. Sebeok (ed.), Style in language. Cambridge: MIT Press; pp. 253-276.

CERECEDA, Verónica (1978a) Mundo quechua. Cochabamba: América Profundo. CEECEDA, Verónica (1978b) "Sémiologie des tissus andins" en Annales. Economies Sociétés Civilisations 33(5-6): 1017-35.

CERRÓN-PALOMINO, Rodolfo M. (1985). Sobre el nombre ‘quechua' en Lexis 9: 87-99. CERRÓN-ÁLOMINO, Rodolfo M. (1987). Linguiística quechua. Cuzco: Centro de Estudios Rurales Andinos 'Bartolomé de las Casas'.

CIEZA DE LEÓN, Pedro (1967) [1550] El señorío de los Incas. Lima: Instituto de Estudios Peruanos.

CLIFFORD, James (1988) The predicament of culture, Twentieth-century ethnography, literature, and art. Cambridge: Harvard University Press.

COHEN, John (1984) "Your struggle is your glory" (cassette). Berkeley: Arhoolie Records. COHEN, John (2002) "Ritual and festival" en Ann Pollard Rowe \& John Cohen (eds.), Hidden threads of Peru, Q'ero textiles. Washington: The textile Museum; pp. 133-155.

COLE, John T. (1969) The human soul in the Aymara culture of Pusamara: An ethnographic study in the light of George Herbert Mead and Martin Buber. Tesis doctoral en antropología, University of Pennsylvania.

CONTRERAS HERNÁNDEZ, Jesús (1985) Subsistencia, ritual y poder en los Andes. Barcelona: Mitre.

CUBA de NORDT, Carmela (1971) "La velada del ganado en la noche de San Juan" en Allpanchis Phuturinqa 3; pp.175-177.

CUMMINS, Thomas B.F. (2009) "The golden calf in America” en Michael W. Cole \& Rebecca Zorach (eds.), The idol in the age of art. Franham: Ashgate; pp. 77-104.

CURATOLA PETROCCHI, Marco (2009) “La función de los oráculos en el Imperio inca” en Marco Curatola Petrocchi \& Mariusz Ziółkowski (eds.) Adivinación y oráculos en el mundo andino antiguo. Lima: Institut français d'Études Andines \& Pontificia Universidad Católica del Perú; pp. 1-54 
CUSTRED, Glynn (1978) "The theme of social transformation in Andean oral tradition" en Roswith Hartmann \& Udo Oberem (eds.), Amerikanistische Studien, Festschrift fur Hermann Trimborn. St. Augustin: Anthropos-Institut, t. 1: 112-120.

CUSTRED, Glynn (1979) "Symbols and control in a high altitude Andean community" en Anthropos 74; pp. 379-392.

DENTAN, Robert Knox (1988). Butterflies and bug hunters: Reality and dreams, dreams and reality. Psychiatry Journal of the University of Ottawa 13: 51-59.

DURKHEIM, Émile (1898) Les règles de la méthode sociologique. Paris:Félix Alcan.

EGGAN, Fred (1954) "Social anthropology and the methos of controlled comparison" en American Anthropologist 56; pp. 743-763.

ERRINGTON,J.Joseph (1985) "On the nature of the sociolinguistic sign:Describing the Javanesespeechlevel" enElizabethMertz\&RichardJ.Parmentier(eds.),Semioticmediation:Socioculturaland psychological perspectives. Orlando:Academic;pp.287-309. ERRINGTON, J. Joseph (1988) Structure and style in Javanese: A semiotic view of linguistic etiquette. Philadelphia: University of Pennsylvania Press.

EWING, Katherine P. (1990). The dream of spiritual initiation and the organization of self representation among Pakistani Sufis en American Ethnologist 17; pp.56-74.

FAVRE, Henri (1966). Tayta wamani: Le culte des montagnes dans le centre sud des Andes péruviennes en Colloque d'études péruviennes. Annales de la Faculté des Lettres, Université de Provence 61 ; pp. 121-140.

FEIBLEMAN, James K. (1946). An introduction to Peirce's philosophy. Cambridge: MIT Press.

FEYERABEND, Paul (1987). Creativity: A dangerous myth en Critical Inquiry 13; pp. 700711.

FLANNERY, Kent V., Joyce MARCUS, and Robert G. REYNOLDS (1989). The flocks of the Wamani; A study of llama herders on the punas of Ayacucho, Peru. San Diego: Academic Press.

FLORES GALINDO, Alberto (1987). Buscando un Inca: Identidad y utopía en los Andes. Lima: Instituto de Apoyo Agrario.

FLORESOCHOA,JorgeA.(1972) “Yestasidolatríasnopudieron ser extirpadas" en Saqsaywaman, Revista del Patronato Departamental deArqueología del Cuzco 2; pp.195-210. FLORES OCHOA, Jorge A. (1976). "Enqa, enqaychu, illa, y khuya rumi, aspectos mágicos-religiosos entre pastores" en Journal of Latin American Lore 2; pp.115136.

FRANQUEMONT, Christine Robinson (1988). Chinchero plant categories: An Andean logic of classification. Tesis doctoral en antropología, Cornell University.

FRIEDRICH, Paul (1966) [1977]. Structural implications of Russian pronominal usage en Language, context and the imagination. Stanford: University Press; pp. 63-125. FRIEDRICH, Paul (1986) "The poetry of language in the politics of dreams" en The language parallax. Austin: University of Texas Press; pp. 65-83.

GEERTZ, Clifford (1973). The interpretation of cultures. New York: Basic. 
GISBERT, Teresa (1981). Iconografía y mitos indígenas en el arte. La Paz: Gisbert.

GOW, Rosalind and Bernabé CONDORI (eds.) (1976). Kay pacha, tradición oral andina. Cuzco: Centro de Estudios Rurales Andinos "Bartolomé de las Casas".

GUAMÁN POMA de AYALA, Felipe (1615) El primer nueva corónica y bven gobierno. http://www.kb.dk/permalink/2006/poma/info/es/frontpage.htm, 16 de mayo de 2015 16:00h.

GUSS, David M. (1980). Steering for dream: Dream concepts of the Makiritare. Journal of Latin American Lore 6: 297-312.

HARRISON, Regina (2014). Sin and Confession in Colonial Peru. Spanish-Quechua Penitential Texts, 1560-1650. Austin: University of Texas Press.

HERDT, Gilbert (1987). "Selfhood and discourse in Sambia dream sharing" en Barbara Tedlock (ed.), Dreaming, anthropological and psychological approaches. Cambridge: University Press; pp. 55-85.

HERNÁNDEZ, Principe, Rodrigo (1622). “Idolatrías de Recuay” en Inca I (l); pp. 25-49 (1923).

HERRERA y GARMENDIA, Fortunato L. (1938). "Plantas que curan y plantas que matan de la flora del Cuzco" en Revista Universitaria 75; pp. 4-76.

HICKMAN, John Marshall (1963). Los aymara de Chinchera, Perú: persistencia y cambio en un contexto bicultural. México (D.F.): Instituto Indigenista Interamericano, edición de 1975.

HOCQUENGHEM, Anne-Marie (1987). Iconografía mochica. Lima: Fondo Editorial de la Pontificia Universidad Católica del Perú.

HOLLAN, Douglas (1989). "The personal use of dream beliefs in the Toraja highlands" en Ethos 17: pp. 166-186.

HOPKINS, Diane E. (1982). "Juego de enemigos: La interpretación de una batalla ritual de 1772 en el sur del Perú desde una perspectiva histórica y simbólica” en Allpanchis Phuturinqa 20 ; pp.167-187.

HORSWELL, Michael (2005). Decolonizing the Sodomite. Queer Tropes of Sexuality in Colonial Andean Culture. Austin: University of Texas Press.

HOWARD, Rosaleen (1989). "Storytelling strategies in Quechua Narrative Performance" en Journal of Latin American Lore 15 (1); pp. 3-71. HOWARD, Rosaleen (2012). "Shifting voices, shifting worlds. Evidentiality, epistemic modality and speaker perspective in Quechua oral narrative” en Pragmatics and Society 3; pp. 243-269.

HUAYHUA, Margarita. (2010). Runama kani icha alquchu?: Everyday discrimination in the Southern Andes. Tesis doctoral en antropología, University of Michigan.

HUSSON, Jean Philippe. (2000). "Dialogues asymétriques dans le cycle dramatique de la mort d'Atawallpa (pérou-Bolivie)» en Aurore Monod-Becquelin \& Philippe Erikson (eds.), Les rituels du dialogue, Paris: Société d'Ethnologie ; pp. 255-281. HUSSON, Jean Philippe (2006). « ¿Testimonio histórico o invención? La cuestión de la autenticidad de la Tragedia del fin de Atawallpa » en Paccarina (Lima) 1 ; pp. 25-38. 
ISBELL, Billie Jean (1978). To defend ourselves: Ecology and ritual in an Andean village. Austin: University of Texas Press.

ITIER, César (2000). “¿Visión de los vencidos o falsificación? datación y autoría de la Tragedia de la muerte de Atahualpa” en Bulletin de l'Institut Français d'Études Andines 30(1); pp. 203-121

JIMÉNEZ BORJA, Arturo (1961). "La noche y el sueño en el antiguo Perú” en Revista del Museo Nacional (Lima) 30; pp. 85-95.

KAMEN, Henry A.F. (1985). Inquisition and society in Spain in the sixteenth and seventeenth centuries. Bloomington: Indiana University Press.

KIM, Seong Nae (1989). "Lamentations of the dead: The historical imagery of violence on Cheju Island, South Korea” en Journal of Ritual Studies 3; pp. 251-285.

KOHN, Eduardo (2012). "How dogs dream. Amazonian natures and the politics of transspecies engagement" en American Ethnologist 34; pp. 3-24.

KOHN, Eduardo (2013). How forests think. Toward an anthropology beyond the human. Berkeley: University of California Press.

KRACKE, Waud (1987). "Myths in dreams, thoughts in images: An Amazonian contribution to the psychoanalytic theory of primary processes en Barbara Tedlock (ed.) Dreaming, anthropological and psychological approaches. Cambridge: University Press; pp. 31-54.

LARA, Jesús (1957). Atau Wallpaj p’uchukakuyninpa wankan, Tragedia del fin de Atawallpa. Cochabamba: Universitaria.

LARA, Jesús (1971). Diccionario qheswa-castellano, castellano-qheswa. La Paz: Los Amigos del Libro.

LA RIVA GONZÁLEZ, Palmira (2010). « Rêves de fleurs et rêves de fruits. Une construction andine du genre » en Journal de la Société des Américanistes 96 (2).

LÉVI-STRAUSS, Claude (1959). "La geste d'Asdiwal » en Annuaire, École Pratique des Hautes Études. Section des sciences religieuses, 1958-1959 ; pp. 3-43.

LIENHARDT, R. Godfrey (1961). Divinity and experience: the religion of the Dinka. Oxford: Clarendon Press.

LIRA, Jorge A. (1944). Diccionario Kkechuwa-Español. Tucumán: Universidad Nacional de Tucumán.

LÓPEZ-BARALT, Mercedes (1979). La persistencia de las estructuras simbólicas andinas en los dibujos de Guamán Poma de Ayala. Journal of Latin American Lore 5: 83-116. (1987). El yana k'uychi o arco iris negro en la elegía a Atahualpa, una mirada a le metáfora andina de la liminalidad desde una perspectiva cultural. En: El retorno del Inca Rey: Mito y profecía en el mundo andino. Madrid: Playor, pp. 13-35.

MACDONALD, Theodore (1979). Processes of change in Amazonian Ecuador. Tesis doctoral en antropologia, University of Illinois at Urbana.

MANNHEIM, Bruce (1986). "Popular song and popular grammar, poetry and metalanguage” en Word, 37; pp.45 75. 
MANNHEIM, Bruce (1987). "A semiotic of Andean dreams" en Barbara Tedlock (ed.), Dreaming, anthropological and psychological approaches.. Cambridge: University Press; pp. 132153.

MANNHEIM, Bruce (1991). The language of the Inka since the European invasion. Austin: University of Texas Press.

MANNHEIM, Bruce (1999). "Hacia una mitografía andina en Juan-Carlos Godenzzi (ed.), Tradición oral andina y Amazónica. Métodos de análisis e interpretación de textos, Cuzco: Centro de Estudios Regionales Andinos "Bartolomé de las Casas"; pp. 57-96.

MANNHEIM, Bruce (2000). "El arado del tiempo: poética quechua y formación nacional” en Revista Andina 17(33); pp. 15-54.

MANNHEIM, Bruce (2015a). The horn of time. En preparación, Department of Anthropology, University of Michigan.

MANNHEIM, Bruce (2015b). "Juan de Pérez Bocanegra ( $i-1645)$ ” en Joanne Pillsbury (ed.); Ximena Fernández Fontenoy (tr.), Guía a las fuentes documentales en estudios andinos, 1530-1900, Lima: Fondo Editorial de la Pontificia Universidad Católica del Perú.

MANNHEIM, Bruce \& Susan A. GELMAN (2013). "El aprendizaje de los conceptos genéricos entre niños quechua hablantes monolingües" en Bulletin de l'Institut Français d'Études Andines 42(3).

MANNHEIM, Bruce \& Guillermo SALAS CARREÑO (2014). "Wak'a: Entifications of the Andean sacred" en Tamara Bray (ed.), The Archaeology of Wak'as: Explorations of the Sacred in the pre-Columbian Andes, Boulder: University of Colorado Press; pp. $46-62$

MANNHEIM, Bruce \& Krista E. van VLEET (2000). "Surtout, ne vous endormez jamais dans un bus»: la dialogisme dans la narration quéchua méridionale » en Aurore Monod-Becquelin \& Philippe Erikson (eds.), Les rituels du dialogue, Paris: Société d'Ethnologie ; pp. 29-78.

MCDOWELL, John Holmes (1989). Sayings of the ancestors: The spiritual life of the Sibundoy Indians. Lexington: The University Press of Kentucky.

MOLINA, Cristóbal de, 'el Cuzqueño' (1943) [1574]. Relación de las fabulas y ritos de los Yngas.... Biblioteca Nacional de Madrid, manuscrito 3169, fs. 2-36. Editado en F.A. Loayza (ed.), Las crónicas de los Molinas.. Lima. paginación 2; pp. 3-84.

MOORE, Sally Falk and Barbara MEYERHOFF (1977). "Secular ritual: forms and eanings" en Secular ritual. Assen: van Gorcum; pp. 3-24.

MOROTE BEST, Efraín (1953). Aldeas sumergidas. Folklore Americano 1; pp.45-81.

MORRIS, Charles (1938). Foundations of the theory of signs (International Encyclopedia of Unified Science 1.2). Chicago: University of Chicago Press.

MOYA, Ruth (1987). Símbolos oníricos. En: Ecuador: cultura, conflicto y utopía. Quito: CEDIME, pp. 195-200.

MOYA, Ruth (1988). Girando en torno a sueños y creencias. Quito: CEDIME. 
ORCAín, Pablo José de (1906) [1790]. "Compendio breve de discursos varios sobre diferentes materias y noticias geográficas comprehensivas a este obispado del Cuzco escrito en la villa de Andaguaylillas del partido de Quispicanche" en Víctor M. Maúrtua (ed.), Juicio de límites entre el Perú y Bolivia, Prueba peruana presentada al gobierno de la Republica Argentina, t. 11, Obispados y Audiencia del Cuzco. Barcelona: Henrich.

ORTIZ RESCANIERE, Alejandro (1973). De Adaneva a Inkarri: una visión indígena del Perú. Lima: Instituto Nacional de Investigation y Desarrollo de la Educación. ORTIZ RESCANIERE, Alejandro (1977). Huarochirí, cuatrocientos años después. Lima: Departamento de Ciencias Sociales, Pontificia Universidad Catolica del Peru.

ORTNER, Sherry B. (1978). Sherpas through their rituals. Cambridge: University Press.

OSSIO ACUÑA, Juan M., ed. (1973). Ideología mesiánica del mundo andino. Lima: Ignacio Prado Pastor.

PARKER, Gary J. (2013). Trabajos de linguiística histórica quechua (ed. por Rodolfo Cerrón-Palomino sobre la base de publicaciones informales de 1969-1971) Lima: Fondo Editorial de la Pontificia Universidad Católica del Perú.

PARMAN, Susan (1991). Dream and culture: an anthropological study of the western intellectual tradition. New York: Praeger.

PAZ VILLAROEL, Luis Alberto (1971). "Fiesta del cordero" en Allpanchis Phuturinqa 3; pp. 178-181.

PEIRCE, Charles Sanders (1931). Collected papers, t. 2. Cambridge: Harvard University Press.

PÉREZ [de] BOCANEGRA, Juan de (1631). Ritual formulario e institucion de Curas para administrar a los naturales de este Reyno los Santos Sacramentos... por el Bachiller Joan Perez Bocanegra, presbiterio, en la lengua quechua general. Lima: Gerónimo de Contreras.

PERRIN, Michel (1992). Les praticiens du rêve. Paris : PUF.

PRELORAN, Mabel (1987). "Los sueños en la cultura otavaleña” en Ecuador Indígena: Simbolismo y cotidianidad, Otavalo: Instituto Otavaleño de Antropología \& Abya-Yala; pp. 97-118.

PUTNAM, Hilary (1975)."The meaning of 'meaning" en Mind, language, and reality. Cambridge: University Press; pp. 215-271.

QUINE, Willard Van Orman (1960). Word and object. Cambridge: MIT Press.

QUISPE M., Ulpiano (1969). La herranza en Choque Huarcaya y Huancasancos, Ayacucho. Instituto Indigenista Peruano. Monografia 20.

RAPPAPORT, Roy A. (1976). "Liturgies and lies" en International Yearbook for the Sociology of Knowledge and Religion 10; pp. 75-104.

ROOT, Deborah (1988). "Speaking Christian: Orthodoxy and difference in Sixteenthcentury Spain" en Representations 23; pp.118-34.

SALAS CARREÑO, Guillermo (2015). "Places are kin”. En preparación, Departamento de Antropología, Pontificia Universidad Católica del Perú. 
SÁNCHEZ PARGA, José (1991). "Antropologías del sueño” en Ecuador Debate 22; pp. 88-90.

SAN PEDRO, Juan, Antonio LOZANO, Juan RAMIREZ \& Juan del CANTO [Primeros Agustinos] (1865) [1559]. Relación de la religión y ritos del Perú hecha por los primeros religiosos agustinos que allí pasaron para la conversión de naturales. En: Colección de documentos inéditos relativos al descubrimiento, conquista y colonización de las posesiones españoles en América y Oceanía, t. 3. Madrid: Quiros. Pp. 5-58

SANTACRUZ PACHACUTI YAMQUI, Juan de (1613). Relación de antigüiedades deste reyno del Piru. Manuscrito 3169, ff. 132-169. Biblioteca Nacional, Madrid. Edición de Carlos Araníbar, 1995. Lima: Fondo de Cultura Económica.

SAPIR, Edward (1916). Time perspective in aboriginal American culture: A study of method. Canadian Department of Mines Geological Survey, Memoir 90. Ottawa: Government Printing Bureau.

SAPIR, Edward (1921). Language. New York: Harcourt Brace and World.

SAUSSURE, Ferdinand de (1915). Cours de linguistique generale. C. Bally, A. Sechehaye, $\&$ A. Reidlinger (eds.), Paris: Payot.

SHAW, Rosalind (1992). "Dreaming as accomplishment: Power, the individual, and Temne divination" en: M.M. Charles Jedrej \& Rosalind Shaw (eds.), Dreaming, religion, and society in Africa. Leiden: Brill; pp. 36-54.

TAMBIAH, Stanley J. (1981) "A performative approach to ritual" en Culture, thought, and social action. Cambridge: Harvard University Press; pp. 123-166.

TANDIOY JANSASOY, Francisco (1987) Muscuycuna y tapiacuna: Sueños y aguieros en inga y castellano. Pasto: Comité de Educación Inga de la Organización Musu Runacuna.

TAYLOR, Marjorie and Susan A. GELMAN (1988) "Adjectives and nouns: Children's strategies for learning new words" en Child Development 59; pp. 411-419.

TEDLOCK, Barbara (1987) "Dream sharing and dream interpretation in two cultures" en Barbara Tedlock (ed.), Dreaming, anthropological and psychological approaches, Cambridge: University Press; pp. 105-31.

TEDLOCK, Dennis (1971) "On the translation of style in oral narrative" en The spoken word and the work of interpretation. Philadelphia: University of Pennsylvania Press, 1985; pp. 31-61

THOMPSON, Stith (1950) Motif. Funk and Wagnalls standard dictionary of folklore and mythology. New York: Funk and Wagnalls, t. 2; p. 753.

TORERO, Alfredo (1974). El quechua y la historia social andina. Lima: Universidad Ricardo Palma.

TURNER, Terence S. (1969). "Oedipus: Time and structure in narrative form en Forms of symbolic action" en Proceedings of the American Ethnological Society. Seattle: University of Washington Press; pp. 26-69.

TURNER, Victor W. (1968) The drums of affliction, A study of religious processes among the Ndembu of Zambia. Oxford: Clarendon Press. 
TURNER, Victor W. (1973) "Symbols in African ritual" en Science 179; pp.1100-1105.

URTON, Gary (1981) At the crossroads of the earth and the sky: An Andean cosmology. Austin: University of Texas Press.

VAN DE GUCHTE, Maarten J.D. (1991). "Carving the world": Inca monumental sculpture and landscape. Tesis doctoral en antropología, University of Illinois at UrbanaChampaign.

VIVANCO FLORES, Carlos A. (1971) "La noche de San Juan en la versión Chanca" en Allpanchis Phuturinqa 3 ; pp. 172-174.

WACHTEL, Nathan (1967) " La vision des vaincus: La conquête espagnole dans le folklore indigène » en Annales: Économies Sociétés Civilisations 22 ; pp. 554-85. WACHTEL, Nathan (1971) La vision des vaincus, Les Indiens de Pérou devant la conquête espagnole. Paris: Gallimard.

WALLACE, Anthony F.C. (1961). Culture and personality. New York: Random House.

WEBSTER, Steven S. (1971). The social organization of Native Andean community. Tesis doctoral en antropología, University of Washington.

WHITEHEAD, Harriet (1987). Renunciation and reformulation, A study of conversion in an American sect. Ithaca: Cornell University Press.

WHITTEN, Dorothea S. and Norman WHITTEN (1988). From myth to creation. Urbana: University of Illinois Press.

WHITTEN, Norman (1976). Sacha Runa. Urbana: University of Illinois Press.

ZAMBRANO, Maria (1957). "Dreams and time" en Diogenes 20; pp. 32-41.

ZUIDEMA, R. Tom (1970). "Social versus structural change in Quechua society of southern Peru" en Anniversary contributions to anthropology. Leiden: Brill; pp. 153-158. ZUIDEMA, R. Tom (2011). El calendario Inca. Tiempo y espacio en la organización ritual del Cuzco. Lima: Fondo Editorial de la Pontificia Universidad Católica del Perú.

ZUIDEMA, R. Tom and Ulpiano QUISPE (1968). "A visit to god: The account and interpretation of a religious experience in the Peruvian community of Choque Huarcaya" en Bijdragen tot de Taal-, Land-, en Volkenkunde 124; pp. 22-39. 